\title{
Acceptability of telephone support as perceived by patients with cancer: a systematic review
}

DOI:

10.1111/ecc. 12643

\section{Document Version}

Accepted author manuscript

Link to publication record in Manchester Research Explorer

\section{Citation for published version (APA):}

Liptrott, S., \& Bee, P. (2017). Acceptability of telephone support as perceived by patients with cancer: a systematic review. European Journal of Cancer Care. https://doi.org/10.1111/ecc.12643

\section{Published in:}

European Journal of Cancer Care

\section{Citing this paper}

Please note that where the full-text provided on Manchester Research Explorer is the Author Accepted Manuscript or Proof version this may differ from the final Published version. If citing, it is advised that you check and use the publisher's definitive version.

\section{General rights}

Copyright and moral rights for the publications made accessible in the Research Explorer are retained by the authors and/or other copyright owners and it is a condition of accessing publications that users recognise and abide by the legal requirements associated with these rights.

\section{Takedown policy}

If you believe that this document breaches copyright please refer to the University of Manchester's Takedown Procedures [http://man.ac.uk/04Y6Bo] or contact uml.scholarlycommunications@manchester.ac.uk providing relevant details, so we can investigate your claim.

\section{OPEN ACCESS}




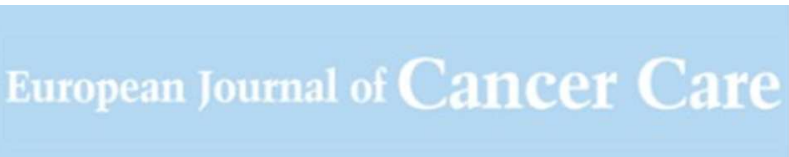

\section{Acceptability of telephone support as perceived by patients with cancer: a systematic review}

\begin{tabular}{|r|l|}
\hline Journal: & European Journal of Cancer Care \\
\hline Manuscript ID & ECC-2016-0112.R1 \\
\hline Manuscript Type: & Feature and Review Paper \\
\hline Keywords: & Cancer, telephone, acceptability, satisfaction, support, systematic review \\
\hline \multicolumn{2}{|c}{} \\
\hline
\end{tabular}

SCHOLARONE $^{\text {MT }}$

Manuscripts 
Please find attached the revised manuscript entitled, 'Acceptability of telephone support as perceived by patients with cancer: a systematic review', for consideration for publication in the European Journal of Cancer Care.

We have taken on board the comments of the reviewers and amended the paper accordingly, making reference where the corresponding modifications have been made.

This manuscript describes original work and is not under consideration by any other journal. All authors approved the manuscript and this submission.

Thank you for receiving our manuscript and considering it for review. We appreciate your time and look forward to your response.

Kind regards

Sarah Liptrott 


\section{Abstract:}

Telephone-based interventions can increase accessibility to healthcare and are increasingly used as a convenient method of providing support. We conducted a systematic review of published literature reporting adult patients' perceptions of the acceptability of, and satisfaction with, telephone-based interventions during or post-treatment for cancer. Systematic searches identified 4855 articles. Forty-eight papers describing 50 studies were included in the review. Three intervention categories were identified post-hoc: a) telephone follow-up in lieu of routine hospital follow-up, b) telephone interventions for treatment side-effect monitoring and toxicity management supplementary to usual care, and c) supplementary psycho-educational telephone interventions. Across studies, some consistent findings emerged. Positive perceptions emphasised the convenience of telephone interventions and increased accessibility to care. Conflicting perceptions of the quality of the support received, the impact of telecare on the patient-healthcare professional relationship and the need for such interventions emerged.

In conclusion, the evidence base relating to patients' perceptions of telephone-based interventions is increasing. Interpretation of findings is currently limited by methodological limitations in the primary research. The instruments chosen to assess patient satisfaction quantitatively do not always reflect the patient-centred priorities that emerge from qualitative data. Subsequent research would benefit from well-designed qualitative studies and patient-centred outcome measures to ensure that the individuality of participants' positive and negative experiences are captured.

Keywords: cancer, telephone, acceptability, satisfaction, support, systematic review 


\section{Background}

Approximately 14.1 million people worldwide are diagnosed with cancer per year (Cancer Research UK. 2014) and with ongoing treatment development, long-term prognosis is improving. Treatment for cancer is increasingly outpatient-based and patients are often discharged early to reduce hospital stays (Van Tiel et al. 2005). Potential or on-going side effects are managed at home. Inadequate management of symptoms such as fatigue and pain can impact on patient mood and psychological wellbeing with subsequent implications for functional status (Dodd et al. 2001). The need for optimal monitoring of side-effect evolution, and management and support for patients continuing complex therapies in the community is clear.

Support for patients dealing with cancer and its treatments is available and largely evidence-based, with systematic reviews evaluating a variety of psychological (Parahoo et al. 2013; Mustafa et al. 2013) and symptom management (Rueda et al. 2011; Cramp et al. 2012) interventions. Such services however must be provided within the context of increasing patient numbers, and finite healthcare resources. Efforts to maximise service efficiency are therefore high on research and practice agendas.

Economic evaluations of telemedicine for the delivery of healthcare interventions suggest that remote interventions can increase cost-effectiveness (Davlos et al. 2009), prevent re-hospitalization (Krumholz et al. 2002), facilitate time-savings (Pare et al. 2007), and enhance service quality and accessibility (Car \& Sheik, 2003). Telephone delivered support, in particular is an expanding field, used across a variety of clinical settings and patient populations (Miastiaen \& Poot, 2006), including surgery, mental health, cardiac and diabetes care. It is increasingly being used in cancer care (Macartney et al. 2012; Stacey et al. 2012) and in the delivery of symptom management interventions (Barsevick et al. 2004; Badger et al. 2005). However, patient and professional preferences for face-to-face support (Kimman et al. 2010a) and resistance to adopt remote 
communication technologies (i.e. e-mail, mobile phone text message, computer-generated calls) (Kleiboer et al. 2010) highlight potential conflict regarding the best method of providing support for patients.

Under the philosophy of patient-centred care, a focus on patients' needs, perspectives and experiences (Epstein et al. 2005) is crucial. Patient satisfaction with care and services is central to evaluating service quality (Martin et al. 2007). Demonstrating satisfaction, however, is not straightforward. Systematic reviews of interventions for cancer patients tend to focus wholly or predominantly on intervention efficacy (Scott et al. 2013; Rueda et al. 2011). A recent systematic review (Dickinson et al. 2014) examining patient satisfaction with technology use for cancer follow-up, reports only quantitative data. In depth qualitative syntheses of patient perspectives are lacking. Where patient perspectives on acceptability have been considered, the term has often intermixed with concepts of 'utility' (Clark et al. 2007), 'benefit' or 'feasibility' (Campbell et al. 2007) and 'value' (Castro et al. 2007). Working definitions of these different constructs are rarely stated, highlighting a blurring of the terms used to elicit patient experiences, and variability in their application as both concepts and outcomes to be measured.

The literature lacks a comprehensive synthesis of patient's perceptions of telephone as a method of providing support for cancer patients both during and after treatment, and of the different research strategies that have been used to measure this concept.

\begin{abstract}
Aims
The aim of this review was to systematically identify and synthesise published literature reporting on patient satisfaction and acceptability of support delivered by telephone for cancer during or posttherapy.
\end{abstract}


The objectives for the study were to a) identify the size and nature of the international evidence base b) assess its methodological quality, and c) synthesise the available to generate a preliminary framework of patients perceptions of satisfaction and acceptability with telephone-based interventions.

\section{Methods}

\section{$\underline{\text { Inclusion criteria }}$}

Studies were included in the review if they described:

(a) data relating to cancer patients perceptions of the acceptability of, or satisfaction with, a healthcare professional initiated telephone intervention. Acceptability and satisfaction were defined as opinions, beliefs, views, attitudes, impressions, experience or perceptions. It is recognised that these are individual but related concepts and all papers with such terms were screened for inclusion in the review in order to capture pertinent literature.

(b) $\geq 75 \%$ of patients were over 18 years of age,

(c) receiving the intervention during or after treatment for cancer, and

(c) the study was published in English language

As the overall aim of the systematic review was to look at acceptability of telephone support as perceived by patients, traditional hierarchies of evidence for intervention effectiveness did not apply. As such a wide variety of sources were included in the search. This included including randomised controlled trials (RCT's), controlled and uncontrolled studies, qualitative studies and theses. Due to concerns regarding study generalizability, individual case studies and conference proceedings were excluded. Study inclusion and exclusion criteria are summarised in Table 1. 


\section{$\underline{\text { Search Strategy }}$}

A systematic search of 13 electronic databases was performed (Table 2), in March 2013 and updated on $17^{\text {th }}$ September 2014. The search strategy used key words (Table 3a), identified from a prior scoping exercise and via discussion within the clinical academic and research team. A condensed list of generic search terms (Table 3b) were used for searches performed in the UKCRN Clinical Trials Portfolio and NIH Clinical Trials Databases. Reference lists of articles were also checked for potentially eligible studies.

\section{$\underline{\text { Selection of studies }}$}

Following the search, a title and abstract screening was performed. All papers were screened for inclusion by one reviewer (SL). An attempt to contact study authors was made where it was unclear whether the study met the inclusion criteria. Reasons for study exclusion are summarised in Table 4. Articles identified as eligible for inclusion by one reviewer were independently reviewed by all other researchers to verify eligibility. The study selection process is shown in Figure 1.

\section{Data extraction}

A study-specific a priori data extraction template was created in order to extrapolate key data of interest. This pro-forma covered (a) study type, (b) data source, (c) study quality indicators, (d) study population (recruitment context, methods, study inclusion and exclusion criteria, number receiving the intervention, number asked about acceptability and providing data), (e) participant characteristics (diagnosis, sex, age, cancer treatment received), (f) intervention description, (g) quantitative acceptability outcome measures, and (h) qualitative acceptability data. Qualitative data were extracted at the level of themes identified and reported within the text of the primary paper. All studies were subject to double blind extraction to ensure accuracy; discrepancies were resolved via team discussion and return to the original paper when required. 


\section{Quality assessment}

Acceptability and satisfaction are two related constructs that can be both quantitatively and qualitatively explored. In this review, the gold standard for research was set as a qualitative investigation or an open-ended question schedule that allowed for patient opinions to be expressed in depth and without limitation, either as a stand-alone study or nested within another study design. Studies using closed-question or a priori designed questionnaires were deemed to be of lower quality due to the potential lack of opportunity for patient-centred perceptions to spontaneously emerge. Each study was initially assessed on the basis of whether a) qualitative data / open-ended questions were used, and b) sufficient data was provided to support the findings. Items were scored 'yes' or 'no' on each criteria and studies were provisionally considered as high quality if they fulfilled both these criteria. Within the higher quality category (i.e. traditional qualitative studies), critical appraisal of individual study quality was then performed (Table 5).

Randomised Controlled Trials (RCT's) reporting patient satisfaction outcomes in both intervention and comparison arms were assessed against the Cochrane Collaboration Risk Bias of Assessment Tool for RCT's (Higgins \& Green, 2011). Non-RCTs, single group designs, were assessed against the relevant Cochrane guidance (Higgins \& Green, 2011). RCT's or nRCTs providing intervention group only data were treated as single group designs and appraised accordingly. Qualitative studies were assessed using the Critical Appraisal Skills Programme (CASP) tool (CASP, 2013).

\section{Methods of data synthesis}

The papers included in the review were synthesised according to the nature of the acceptability data they provided. Themes identified and reported within the text of qualitative studies were summarised, following the principles of thematic synthesis. Heterogeneity in the populations and measurements used to elicit quantitative data, meant that it was it was not possible to perform a meta-analysis. A narrative synthesis of quantitative data was performed. Some studies provided 
both forms of data and contributed to both types of synthesis. The data in each section were different and not double counted.

\section{Results}

A total of 4855 records were identified after duplicate removal (total hits $n=10,423$, duplicates $\mathrm{n}=5568$ ). Based on title and abstract screening, 4611 were rejected. Seventy-eight papers were identified following hand search and reference review. A total of 267 full text articles were reviewed with a further 219 rejected and 48 papers eligible for inclusion (Figure 1). One paper described three studies of different patient populations (Heidrich et al. 2009) and for the purpose of this review; the three studies reported are treated separately. Two papers reported on the same intervention with an overlapping time frame of recruitment, and authors confirmed that some patients had been included in both studies. The two papers (Zheng et al. 2013; Zhang et al. 2013) provided different and complementary forms of data (qualitative and quantitative) and thus, both were included in the review.

\section{$\underline{\text { Study characteristics }}$}

The main characteristics of the 50 studies (from 48 articles) are described in Table 6. All studies were conducted in developed countries, predominantly the US \& Canada, the UK and Australia. Thirty-nine studies reported quantitative data $(\mathrm{n}=39)$. Twenty-four studies provided qualitative data.

Quantitative data were most frequently reported as part of a randomised controlled trial $(\mathrm{n}=17)$, or single group designs $(n=16)$. Qualitative data were collected mainly from stand alone, single group designs $(n=11)$ and nested process evaluations $(n=4)$. 


\section{Quality appraisal}

The review included both qualitative and quantitative data with qualitative data being seen as superior quality.

\section{Qualitative data}

Of the 24 studies providing qualitative data, six were judged to be of high methodological quality (Campbell et al. 2007; Zheng et al. 2013; Archer et al. 2014; Beaver et al. 2010; Donnelly et al. 2013; Wilmoth et al. 2011), with data collected via well-conducted interviews, open-ended questions, or focus groups (Table 5). Three additional studies reported interview but insufficient details regarding study methods or data completeness were provided; these studies were judged lower, or at best unclear, quality (Kilbourn et al. 2013, Livingston et al. 2010; Young et al. 2013).

The remaining studies providing qualitative data $(\mathrm{n}=15)$ including the use of open-ended questions that focused on only one pre-defined aspect of the intervention (Badger et al. 2013), and/or data collection methods relying on written questionnaires, feedback or comments where there was insufficient evidence to confirm completeness of data reporting. These studies were also judged to be of lower quality data (Alter et al. 1996; Badger et al. 2013; Booker et al. 2004; Cimprich et al. 2005; Cox et al. 2008; Dixon 2010; Hafiji et al. 2012; Hagopian \& Rubenstein, 1990; Inman et al. 2011; Kelly 1999; Smithies et al. 2009; Steginga et al. 2008; Young et al. 2010).

\section{Quantitative data}

Quantitative data was provided in 39 studies of which, only two studies used validated measures the Ware's Patient Satisfaction Questionnaire III (Kimman et al. 2010b), and the Satisfaction and Experience of Care Questionnaire (Cox et al. 2008). All other quantitative studies (n=37) used adapted scales or (Salonen et al. 2009; Beaver et al. 2012; Leahy et al. 2013; Cox et al. 2005;), or unvalidated tools specifically designed for the study $(n=34,87 \%)$. Likert scales were used in 21/39 
studies (54\%), with patients responding to set statements on ordinal scales of agreement or disagreement. The number of items used to assess satisfaction was reported in 24/39 studies (62\%), with a median of four items per outcome measure (range 1-42). The majority of studies provided details of the questions asked $(11 / 39,28 \%)$ or some information about which topics were covered $(24 / 39,62 \%)$; these were determined a priori by research teams with no-evidence of bottom-up, patient-led development. A summary of acceptability and satisfaction data quality is provided in Table 7.

\section{$\underline{\text { Sample sizes }}$}

The RE_AIM framework (Glasgow et al. 1999) identifies the reach of health behaviour interventions as an important factor influencing the implementation of research findings into practice. Reach is defined as the number, proportion, and representativeness of individuals who are willing to participate in any given intervention. As such it represents a partial assessment of intervention acceptability, and an indicator of potential selection bias in study samples.

Study participation rates and sample representativeness were inconsistently reported. Sample size was variously defined and it was often unclear whether participant numbers referred to the number of patients who were approached to participate or the number who consented received the intervention, or provided acceptability data.

Twenty-six of the 50 studies provided acceptability data for all participants receiving a telephone intervention. Ten studies (20\%) provided acceptability data for less than $75 \%$ of their sample. Two were notable for providing data for under half of their participants (49\% (Sardell et al. 2000) and 41\% (Archer et al. 2014) respectively. Many participants in the latter study expressing a wish not to take part in an acceptability evaluation. 
In studies providing quantitative satisfaction data $(n=39)$, the number of participants receiving interventions and thus potentially providing satisfaction ratings ranged from 9-387 (median 38 participants). In studies providing qualitative acceptability data $(n=24)$, sample sizes ranged from 8187, median 30.5 participants). The highest sample size in this category $(n=187)$ was achieved in a study reporting feedback and qualitative comments (Hafiji et al., 2012) however it is unclear from how many participants these were collected.

\section{$\underline{\text { Patient characteristics }}$}

Most studies $(n=43)$ tended to be focused on a single cancer type, specifically breast cancer $(n=16)$ colorectal cancer $(n=11)$, or prostate cancer $(n=7)$. Seven studies recruited mixed samples that included patients with different cancer diagnoses. Study participants had received or were still receiving a variety of treatments for their cancer, including surgery, CT, targeted agents, RT or hormone therapy. In a large proportion of studies (48\%), gender and age demographics were only described in terms of the total sample size, and not specific for those who provided data relating to acceptability of the intervention. Mean age across the 41 studies providing data was 60.2 years (SD 6.98). Potential for gender bias was observed; in studies targeting cancers that were not genderspecific, $60 \%$ of participants were male.

\section{$\underline{\text { Characteristics of the interventions }}$}

Intervention content and objectives varied greatly, as well as the timing, duration and format of their delivery. Three main categories of intervention emerged:

\section{Telephone follow-up interventions}

Telephone follow-up (TFU) interventions involved general and cancer symptom monitoring as well as provision of information and support post diagnosis and treatment $(n=6)$. Intervention content and timing typically mirrored that of standard hospital follow-up; the only difference being a 
change in the mode of service delivery. Six studies described structured interventions of this type in patients with breast (Beaver et al. 2010; Beaver et al. 2009), colorectal (Beaver et al. 2012), and prostate cancer (Booker et al. 2004; Leahy et al. 2013; Anderson 2010). All of these interventions were nurse-led.

\section{Treatment side effect / toxicity monitoring}

The second (and largest) category described telephone interventions, which were delivered during and after cancer treatment and focused wholly or predominantly on side effect and toxicity monitoring $(\mathrm{n}=23)$. Some also included side effect management and coping strategies and/or education and information provision. Interventions were often nurse-led and delivered to a variety of cancer patients receiving a variety of treatments. Intervention timing varied according to the specific treatment being received. The vast majority were presented as supplementary to standard care (Heidrich et al. 2009; Zheng et al. 2013; Zhang et al. 2013; Sardell et al. 2000; Jefford et al. 2011; Young et al. 2013; Cox et al. 2008; Dixon 2010; Hagopian \& Rubenstein, 1990; Inman et al. 2011; Smithies et al. 2009; Young et al. 2010; Cirillo et al. 2014; Delaney et al. 2009; Jensen et al. 2011; Mordenti et al. 2013; Munro et al. 1994), although four were described as standard care interventions (Archer et al. 2014; Hafiji et al. 2012; Kelly 1999; Craven et al. 2013).

\section{Psycho-educational interventions}

The third category $(n=21)$ described a wide variety of psycho-educational telephone-based interventions. Almost half were nurse led, although psychologists, physiotherapists, social workers, counsellors and health educators also provided interventions. Thirteen studies reported psychological interventions involving an element of counselling (Alter et al. 1996; Badger et al. 2013; Barsevick et al. 2002; Kim et al. 2011; Marcus et al. 1993, Marcus et al. 2010), coping strategies \& skills training (Campbell et al. 2007; Kilbourn et al. 2013), problem solving (Steginga et al. 2008; Hegel et al. 2011), self-management (Cimprich et al. 2005), cognitive behavioural skills 
training (Sandgren et al. 2000) or intimacy enhancement programs (Reese et al. 2012; Reese et al. 2014). Seven studies described educational and supportive interventions, varying widely in timing and duration (Donnelly et al. 2013; Wilmoth et al. 2006; Livingston et al. 2010; Salonen et al. 2009; Kimman et al. 2010b; Cox et al. 2005; Garrett et al. 2013).

\section{$\underline{\text { Acceptability outcome data }}$}

A summary of outcome data is provided in Table 8 . This table is intended to demonstrate the breadth of factors potentially impacting on intervention acceptability, according to data type and quality. Scales and quantitative data tended to provide more generalised information focusing on positive aspects of interventions such as convenience, accessibility and relationship with the healthcare professional, perceived support and overall satisfaction. Qualitative data presented further insight into opinions of intervention specific components and perceived negative aspects of the interventions. Consistency of findings across studies is indicated.

\section{Findings across all intervention categories}

High quality evidence frequently endorsed that cancer patients valued telephone-based interventions for their convenience. Convenience was reported across intervention categories, in terms of facilitating personal organisation (Beaver et al. 2010), time \& travel savings (Campbell et al. 2007; Jefford et al. 2011), and overcoming participation restrictions (Campbell et al. 2007). Similar findings were also reflected in a further seven studies providing lower quality data (Sardell et al. 2000; Alter et al. 1996; Booker et al. 2004; Cox et al. 2008; Hafiji et al. 2012; Anderson 2010; Hegel et al. 2011).

Positive personal experiences of the intervention process were evident across the three different intervention categories and supported by both higher and lower quality evidence (Beaver et al. 2010; Jefford et al. 2011; Zheng et al. 2013; Donnelly et al. 2013). This included some evidence of 
patient acceptance (Zheng et al. 2013) and appreciation of calls (Donnelly et al. 2013). Nineteen studies providing lower quality evidence echoed these findings, reporting perceptions of intervention helpfulness or usefulness (Heidrich et al. 2009; Livingston et al. 2010; Salonen et al. 2009; Barsevick et al. 2002; Hagopian \& Rubenstein, 1990; Inman et al. 2011; Kelly 1999; Steginga et al. 2008; Munro et al. 1994; Marcus et al. 2010; Reese et al. 2012; Reese et al. 2014; Kim et al. 2011), Barsevick et al. 2002; Cimprich et al. 2005; Hafiji et al. 2012; Delaney et al. 2009; Mordenti et al. 2013; Garrett et al. 2013), ease of participation (Reese et al. 2012; Reese et al 2014) and patient appreciation of the calls (Dixon 2010)

High overall satisfaction was revealed from low quality evidence across the three intervention categories (Heidrich et al. 2009; Zhang et al. 2013; Sardell et al. 2000; Kilbourn et al. 2013; Alter et al. 1996; Badger et al. 2013; Booker et al. 2004; Hafiji et al. 2012; Hagopian \& Rubenstein 1990; Steginga et al. 2008; Kimman et al. 2010b; Leahy et al. 2013; Cox et al. 2005; Beaver et al. 2009; Anderson 2010; Jensen et al. 2011; Craven et al. 2013; Garrett et al. 2013; Hegel et al. 2011). In three studies providing comparative control group analysis, statistically significant greater satisfaction with telephone-based intervention was reported compared with standard hospital care (Zhang et al. 2013; Beaver et al. 2009; Jensen et al. 2011).

\section{Telephone follow-up interventions}

With regards to telephone follow-up in lieu of routine hospital follow-up, high quality evidence suggested that it was important to have access to healthcare professionals, in order to deal with concerns in a timely manner (Beaver et al. 2010). The 'normality' of talking by telephone made this easier (Beaver et al. 2010), and a structured intervention helped to organise thoughts and revisit topics (Beaver et al. 2010). However some participants missed contact with other patients and the reassurance of a physical examination, describing consultations as rushed and impersonal. 


\section{Treatment side effect / toxicity monitoring}

In side effect and post treatment monitoring interventions, high quality findings described the telephone-based approach as more comfortable (Jefford et al. 2011), providing prompt access to health care professionals who could address concerns (Jefford et al. 2011), In particular, high quality evidence from post-surgical monitoring interventions described continuity of care facilitating the transition from hospital to home (Archer et al. 2014) and, during the return to a 'normal life' (Zheng et al. 2013), Whilst a single study described high quality evidence of psychological support (Zheng et al. 2013), lower quality evidence captured concepts with more emotive terminology. This included the benefits of having someone to talk to (Smithies et al. 2009), feeling listened to (Dixon 2010), cared for (Hafiji et al. 2012; Hagopian \& Rubenstein, 1990), showing concern (Inman et al. 2011) and reducing isolation (Kelly 1999), especially in interventions delivered over longer periods of time. The support that was provided was not always deemed necessary however, especially where existing support systems were in place (Young et al. 2013).

Conflicting perceptions of the impact on the patient-HCP relationship were described. High quality evidence highlighted difficulties in dealing with emotions by telephone (Jefford et al. 2011), and matched by opinions from low quality evidence, which suggested a lack of emotional support (Young et al. 2013), a lack of 'enhanced care giving' (Mordenti et al. 2013) and generally poorer knowledge of a patient's case (Young et al. 2013). In direct contrast, other lower quality evidence described positive opinions of the patient-healthcare professional relationship (Sardell et al. 2000; Young et al. 2013; Cox et al. 2008; Dixon 2010; Cirillo et al. 2014).

Low quality evidence alluded to potentially critical aspects of intervention structure, including the need to ensure appropriate call timing (Sardell et al. 2000; Young et al. 2010), and frequency of calls (Hafiji et al. 2012; Kelly 1999), patient choice in receiving calls (Hafiji et al. 2012) and 
consideration of and potential solutions for overcoming language difficulties in calls (Young et al. 2010).

\section{Psycho-educational interventions}

High quality evidence from psycho educational interventions described a telephone based approach as useful especially when dealing with sensitive subjects (Campbell et al. 2007), facilitating a sense of control (Wilmoth et al. 2006). Low quality data findings positively described support (Cimprich et al. 2005), having someone to talk to (Salonen et al. 2009), giving reassurance (Livingston et al. 2010), and having a that is responsive, understands and cares with high levels of participants reporting contact by telephone to be the most helpful component of the intervention (Marcus et al. 2010). One study revealed the impersonal nature of the telephone method (Kilbourn et al. 2013) being a barrier to discussions.

Intervention structure was a theme, with high quality data eliciting the utility of a structured intervention as a memory aid (Wilmoth et al. 2006), promoting accountability and motivation in an exercise and diet program (Donnelly et al. 2013). Lower quality evidence revealed call timing was appropriate for many (Donnelly et al. 2013; Kilbourn et al. 2013; Salonen et al. 2009; Cimprich et al. 2005; Sandgren et al. 2000; Kim et al. 2011), although a lack of control over call timing was described (Sandgren et al. 2000), as well as the influence of treatment side effects interfering with counselling calls (Kilbourn et al. 2013).

Lower quality evidence questioned the suitability of a telephone intervention for all patients on the basis that needs differed between individuals and over time (Zheng et al. 2013), Alternative methods such as group sessions (Cimprich et al. 2005), or face-to-face contact (Sandgren et al. 2000) were preferred by some participants. and in some cases, the intervention had not been useful, as patients already had support (Kilbourn et al. 2013). Despite this, positive perceptions of the patient-healthcare professional relationship were cited in relation to good rapport (Reese et al. 
2014). There was high satisfaction with technical competence (Kimman et al. 2010b; Reese et al. 2014), with high levels of preference for telephone based interventions (Kilbourn et al. 2013; Reese et al. 2012; Reese et al. 2014), although interestingly, two studies described this in terms of negatively worded indicators - with participants "not at all" worried about calls (Livingston et al. 2010), and $0 \%$ of patients "complained about the interview to the interviewer" (Marcus et al. 1993).

\section{Discussion}

We conducted a narrative systematic review of the acceptability of telephone-based interventions for adult cancer patients. The review identified 48 papers reporting on 50 studies. The overall quality of the existing evidence base was not high, as determined by appropriate and validated quality appraisal tools used.

The review included primary research with significant variation in sample size. Smaller samples were evident in 'pilot' or 'feasibility' studies, and larger samples in service evaluations. Participants were often self-selected, raising the possibility of selection bias. In the majority of studies, difficulty in understanding actual numbers of patients approached to participate in studies and the proportion of those accepting to participate remains unclear. A clear understanding of participant characteristics was blurred by a lack of data relating to those participating in the evaluation and whether these were representative of a total group.

Methods to evaluate acceptability and satisfaction were predominantly short quantitative questionnaires, which were not standardised or validated, providing at best generalised, preliminary findings. Although it is recognised that quantitative outcome assessment can be patient-centred, especially when developed from rigorous qualitative insight, findings demonstrated that scales used did not always map directly and wholly on to patient identified concerns identified with more open- 
ended designs. This was especially in relation to issues that were intervention specific and negative opinions.

New, quantitative tools should be developed that enable respondents to be critical, as well as positive about their experience, with items that explore patient perceptions of intervention utility, timing, convenience, accessibility and communication preferences. Reliance on quantitative data in isolation may led to unintentional bias in findings, as patients are known to tend towards positive responses on such instruments (Bradley et al. 2007). There is also potential for a ceiling effect, making differentiation of clustered upper end results challenging, (Dell-Kuster et al. 2014). Employing a mixed methods or qualitative approach may thus be more appropriate.

Qualitative research offers an opportunity to explore patient perceptions in depth, with acceptability defined according to patient priorities and concerns. Qualitative studies however can be conducted for different reasons. Whilst stand-alone studies may explore intervention acceptability from a neutral standpoint, nested process evaluations are often driven by the desire to understand positive or negative intervention effects. The specific objectives of a study may thus determine to some extent whether strengths or limitations of telephone interventions are reported. Rigorous development of evidence-based interventions demands that all potential viewpoints are considered. We thus included all eligible qualitative studies in our review, irrespective of their design or primary objective.

Despite heterogeneity in the intervention categories and the data collection methods, this review, revealed some consistent and potentially important findings. The convenience of telephone delivered interventions was evident across all interventions and data types (Campbell et al. 2007; Beaver et al. 2010; Jefford et al. 2011; Alter et al. 1996; Barsevick et al. 2002; Booker et al. 2004; Cox et al. 2008; Hafiji et al. 2012; Anderson 2010; Hegel et al. 2011). Positive personal experiences were also reported across the different intervention types, although more so in side 
effect/post-treatment monitoring and psycho-educational interventions, where the enhanced communication was viewed as additional component to usual care, (Campbell et al. 2007; Sandgren et al. 2000). Telephone follow-up in lieu of routine hospital follow-up, received more negative feedback and left some patients feeling as though they lacked assurance (Beaver et al. 2010). These potential differences suggest that the nature and setting of the intervention is influential on perceptions of acceptability and satisfaction.

Accessibility to care was a recurrent theme in side effect and post treatment monitoring interventions. Telephone based interventions were often a source of prompt reassurance, continuity of care and information provision to deal with practical issues. The provision of information is recognised as one of the most important factors of supportive cancer care across the trajectory (Husson et al. 2013). Some patients however, reported difficulty receiving emotional support in these interventions (Jefford et al. 2011; Mordenti et al. 2013), that was perhaps reflective of a lack of discussion around psychosocial well-being issues (Taylor et al. 2011). More holistic and complex interventions with a psychosocial component may be required to address this practice gap.

The need for patient choice is noted throughout the review, in terms of satisfaction with the intervention content (Jefford et al. 2011), but more so in recurrent findings relating to a lack of choice over intervention delivery mode (Hafiji et al. 2012), and call timing (Jefford et al. 2011; Kilbourn et al. 2013; Hafiji et al. 2012; Kelly 1999; Sandgren et al. 2000). Both higher and lower quality data suggests that the utility of telephone-delivered interventions may be enhanced when they are shaped by and respond to individual patient need (Zheng et al. 2013; Kilbourn et al. 2013; Young et al. 2013; Hafiji et al. 2012) rather than a global guideline. Patient participation and involvement in care planning is seen as a core element of patient-centred care (Kitson et al. 2010), without which, services may be delivered and resources employed wastefully. Clearer identification 
of patients' needs at specific time points during the cancer journey, and choice of access to services may aid in providing truly patient-centred care.

Whist the majority of studies indicated the potential positive effect of telephone delivered interventions on patient-provider relationships and health care communication, a small number alluded to a negative impact (Beaver et al. 2010; Young et al. 2013; Delaney et al. 2009; Mordenti et al. 2013), and patient preferences for alternative methods of contact (Cimprich et al. 2005; Sandgren et al. 2000). These findings are evident in lower quality quantitative data and reflected in a few studies providing higher quality qualitative data. Nevertheless, the depth of understanding in relation to motivators for such responses is lacking. The impact of telephone delivery on professional-patient relationships is one area that may benefit from further qualitative investigation into different stakeholder perspectives.

High levels of overall satisfaction (Heidrich et al. 2009; Zhang et al. 2013; Sardell et al. 2000; Kilbourn et al. 2013; Alter et al. 1996;, Badger et al. 2013; Booker et al. 2004; Hafiji et al. 2012; Hagopian \& Rubenstein 1990; Steginga et al. 2008; Kimman et al. 2010b; Leahy et al. 2013; Cox et al. 2005; Beaver et al. 2009; Anderson 2010; Jensen et al. 2011; Craven et al. 2013; Garrett et al. 2013; Hegel et al. 2011) were reported, however interpretation of these results should take into account the context of this assessment. Findings from low quality data and in some cases feedback were provided during the delivery of a telephone intervention (Booker et al. 2004; Kelly 1999; Anderson 2010; Craven et al. 2013), with potential for respondent and social desirability biases. Despite being a 'comforting' indicator, overall satisfaction as a measure does not provide sufficient detail to enable key features of intervention design to be identified and maximised.

To our knowledge, this is the first systematic review of patients acceptability and satisfaction of telephone-delivered for cancer patients both during and after treatment. It incorporates data from a 
variety of research strategies. The methodological approach undertaken was comprehensive and transparent, with a search strategy that the authors believe enabled identification of the majority of papers meeting the inclusion criteria. The approach to include both qualitative (nested and nonnested) and quantitative designs, maximises the likelihood that the full breadth of responses to telephone based care is included in our synthesis. Similarities between the data reported by stand alone and nested process evaluations lends weight to the likely components determining acceptability in practice.

Several limitations to the review are to be acknowledged. Although the review included a variety of methodological approaches, only those with interventions delivered by HCP's were included in order to have a more homogenous level of educational training. This systematic review dealt only with data presented within the original research paper itself, and it is appreciated that word limits and space restrictions for publication may influence selective rather than complete reporting of findings. The review excluded studies that were not published in English, and although a detailed protocol was developed for the review, it is recognised that relevant studies may have been unintentionally missed.

\section{Conclusions}

This systematic review reveals an insight into current published research pertaining to the acceptability and satisfaction of support delivered by telephone for cancer patients during or after therapy. Telephone based interventions are a potential resource that can make healthcare initiatives accessible to a variety of patients, and as such merit further investigation. The growth in telephone delivered interventions, especially in the form of smaller 'pilot' or 'feasibility' studies is evident but more often participants perspectives are not featured within the study aims and therefore are often not part of a rigorous study design, leading to several reports of low quality qualitative data derived through post hoc comments or informal feedback. Subsequent research in this field should reflect 
the need to incorporate a high quality qualitative component, in order to ensure that the individuality of participants and their experiences are represented.

The disease specific nature of the majority of studies and differing nature of the interventions, presents difficulty in generalising findings, however the consistency data emerging from these studies allows a useful understanding of patients perceptions. Current evidence relating to the acceptability and satisfaction of support delivered by telephone for cancer patients during or after therapy suggests it is convenient, provides positive personal experiences, enhances accessibility to healthcare professionals, and provides a familiar environment in which to facilitate potentially sensitive health care discussions. Data synthesis suggests a need for services (and individual, facilitating professionals) to have a clearer understanding of the needs of patients in order to develop truly patient centred interventions that reflect individual's needs and choices. 


\section{References}

Alter C.L., Fleishman S.B., Kornblith A.B., Holland J.C., Biano D., Levenson R., Vinciguerra V., Rai K.R. (1996) Supportive telephone intervention for patients receiving chemotherapy. A pilot study. Psychosomatics. 37(5): 425-31.

Anderson B. (2010) The benefits to nurse-led telephone follow-up for prostate cancer. British Journal of Nursing. 19 (17): 1085-90.

Archer S., Montague J., Bali A.. (2014) Exploring the experience of an enhanced recovery programme for gynaecological cancer patients: a qualitative study. Perioperative Medicine (London). 3(1): 2.

Badger T., Segrin C., Meek P., Lopez A., Bonham E., Sieger B. (2005) Telephone interpersonal counselling for women with breast cancer: Symptom management and quality of life. Oncology Nursing Forum. 32 (2): 273-279.

Badger T., Segrin C., Pasvogel A., Lopez A.M. (2013) The effect of psychosocial interventions delivered by telephone and videophone on quality of life in early-stage breast cancer survivors and their supportive partners. Journal of Telemedicine and Telecare. 19(5): 260-5.

Barsevick A.M., Whitmer K., Sweeney C., Nail L.M. (2002) A pilot study examining energy conservation for cancer treatment-related fatigue. Cancer Nursing. 25(5): 333-41.

Barsevick A., Dudley W., Beck S., Sweeney C., Whitmer K., Nail L. (2004) A randomised clinical trial of energy conservation for patients with cancer-related fatigue. Cancer. 100(6): 1302-10.

Bradley C., Plowright R., Stewart J., Valentine J., Witthaus E. (2007) The Diabetes Treatment Satisfaction Questionnaire change version (DTSQc) evaluated in insulin glargine trials shows greater responsiveness to improvements than the original DTSQ. Health and Quality of Life Outcomes. 5: 57.

Campbell L.C., Keefe F.J., Scipio C., McKee D.C., Edwards C.L., Herman S.H., Johnson L.E., Colvin O.M., McBride C.M., Donatucci C. (2007) Facilitating Research Participation and Improving Quality of Life for African American Prostate Cancer Survivors and Their Intimate 
Partners: A Pilot Study of Telephone-Based Coping Skills Training. Cancer. 109 (Suppl 2): 414424.

Beaver K., Tysver-Robinson D., Campbell M., Twomey M., Williamson S., Hindley A., Susnerwala S., Dunn G., Luker K. (2009) Comparing hospital and telephone follow-up after treatment for breast cancer: randomised equivalence trial. British Medical Journal. 14; 338: a3147.

Beaver K., Williamson S., Chalmers K. (2010) Telephone follow-up after treatment for breast cancer: views and experiences of patients and specialist breast care nurses. Journal of Clinical Nursing. 19: 2916-24.

Beaver K., Campbell M., Williamson S., Procter D., Sheridan J., Heath J., Susnerwala S. (2012) An exploratory randomized controlled trial comparing telephone and hospital follow-up after treatment for colorectal cancer. Colorectal Disease. 14(10): 1201-9.

Booker J., Eardley A., Cowan R., Logue J., Wylie J., Caress AL. (2004) Telephone first postintervention follow-up for men who have had radical radiotherapy to the prostate: evaluation of a novel service delivery approach. European Journal of Oncology Nursing. 8 (4) : 325-33.

Cancer Research UK. Worldwide Cancer. Cancer Research UK. 2014. [online] Available at:< http://publications.cancerresearchuk.org/downloads/product/CS KF_WORLDWIDE.pdf $>$ [Accessed 13 March 2015].

Car J., Sheik A. (2007) Telephone consultations. British Medical Journal. 2003; 326: 966-999.

Clark RA, Inglis SC, McAlister FA, Cleland JGF, Stewart S. Telemonitoring or structured telephone support programmes for patients with chronic heart failure: systematic review and metaanalysis. British Medical Journal. 334(7600): 942.

Castro K., Mitchell S., Rowe T., Jacobs M. (2007) A chronic graft-versus-host disease (cGVHD) telephone support group: partnering with an advocacy organization to address an undeserved population of cancer survivors. Oncology Nursing Forum. 35(3): 514. 
Cimprich B., Janz N.K., Northouse L., Wren P.A., Given B., Given C.W. (2005) Taking CHARGE: A self-management program for women following breast cancer treatment. Psychooncology. 14(9): 704-17.

Cirillo M., Lunardi G., Coati F., Ciccarelli L., Alestra S., Mariotto M., Micheloni B., Cassandrini P.A., Inno A., Magarotto R., Nicodemo M., Picece V., Turazza M., Gori S., Venturini M. (2014) Management of oral anticancer drugs: feasibility and patient approval of a specific monitoring program. Tumori. 100(3): 243-8.

Cox K., Wilson E., Arthur A., Elkan R., Armstrong S. (2005) A randomised controlled trial of nurse-managed trial conclusion following early phase cancer trial participation. British Journal of Cancer. 93(1): 41-5.

Cox A., Bull E., Cockle-Hearne J., Knibb W., Potter C., Faithfull S. (2008) Nurse led telephone follow up in ovarian cancer: a psychosocial perspective. European Journal of Oncology Nursing. 12(5): 412-7. doi: 10.1016/j.ejon.2008.06.002.

Cramp F., Byron-Daniel J. (2012) Exercise for the management of cancer-related fatigue in adults. Cochrane Database of Systematic Reviews. 2012; 11: CD006145.

Craven O., Hughes C.A., Burton A., Saunders M.P., Molassiotis A. (2013) Is a nurse-led telephone intervention a viable alternative to nurse-led home care and standard care for patients receiving oral capecitabine? Results from a large prospective audit in patients with colorectal cancer. European Journal of Cancer Care (England). 22(3): 413-9.

Critical Appraisal Skills Programme. (2013). Qualitative Research Checklist. [online] Available at:<http://media.wix.com/ugd/dded87_29c5b002d99342f788c6ac670e49f274.pdf>

[Accessed 05 June 2014]. 
Davalos M.E., French M.T., Burdick A.E., Simmons S.C. (2009) Economic evaluation of telemedicine: review of the literature and research guidelines for benefit-cost analysis. Telemedicine Journal and e-Health. 15(10): 933-948.

Delaney L., Chambers C., Roldán G., De Robles P., Cairncross G., Forsyth P., Easaw J. (2009) A feasibility study to assess the integration of a pharmacist into neurooncology clinic. Journal of Oncology Pharmacy Practice. 15(2): 79-85.

Dell-Kuster S., Sanjuan E., Todorov A., Weber H., Heberer., Rosenthal R. (2014) Designing questionnaires: healthcare survey to compare two different response scales. BMC Medical Research Methodology. 14:96.

Dickinson R., Hall S., Sinclair J., Bond C., Murchie P. (2014) Using technology to deliver cancer follow-up: a systematic review. BMC Cancer. 14:311.

Dixon W. (2010) The Feasibility of Telephone Follow-up Led by a Radiation therapist: Experience in a Multidisciplinary Bone Metastases Clinic. Journal of Medical Imaging and Radiation Sciences. 41(4): 175-179.

Dodd M., Miaskowski C., Paul S. (2001) Symptom clusters and their effect on the functional status of patients with cancer. Oncology Nursing Forum. 28(3): 465-70.

Donnelly C.M., Lowe-Strong A., Rankin J.P., Campbell A., Blaney J.M., Gracey J.H. (2013) A focus group study exploring gynecological cancer survivors' experiences and perceptions of participating in a RCT testing the efficacy of a home-based physical activity intervention. Supportive Care in Cancer. 21(6): 1697-708.

Epstein R.M., Franks P., Fiscella K., Shields C.G., Meldrum S.C., Kravitz R.L., Duberstein P.R. (2005) Measuring patient-centred communication in patient-physician consultations: theoretical and practical issues. Social Science and Medicine. 61(7): 1516-28.

Garrett K., Okuyama S., Jones W., Barnes D., Tran Z., Spencer L., Lewis K., Maroni P., Chesney M., Marcus A. (2013) Bridging the transition from cancer patient to survivor: pilot study results of the Cancer Survivor Telephone Education and Personal Support (C-STEPS) program. Patient 
Education and Counselling. 92(2): 266-72.

Glasgow R.E., Vogt, T.M., Boles, S.M. (1999) Evaluating the public health impact of health promotion interventions: the RE-AIM Framework. American Journal of Public Health. 89: 13221327.

Hafiji J., Salmon P., Hussain W. (2012) Patient satisfaction with post-operative telephone calls after Mohs micrographic surgery: a New Zealand and U.K. experience. British Journal of Dermatology. 167(3): 570-574.

Hagopian G., Rubenstein J.H. (1990) Effects of telephone call interventions on patients' well-being in a radiation therapy department. Cancer Nursing. 13(6): 339-44.

Hegel M.T., Lyons K.D., Hull J.G., Kaufman P., Urquhart L., Li Z., Ahles T.A. (2011) Feasibility study of a randomized controlled trial of a telephone-delivered problem-solving-occupational therapy intervention to reduce participation restrictions in rural breast cancer survivors undergoing chemotherapy. Psychooncology. 20(10):1092-101.

Heidrich S.M., Brown R.L., Egan J.J., Perez O.A., Phelan C.H., Yeom H., Ward S.E. (2009) An individualized representational intervention to improve symptom management (IRIS) in older breast cancer survivors: three pilot studies. Oncology Nursing Forum. 36(3): E133-43.

Higgins J.P.T., Green S. (editors). (2011) Cochrane Handbook for Systematic Reviews of Interventions Version 5.1.0 [updated March 2011]. The Cochrane Collaboration. Available from www.cochrane-handbook.org.

Husson O., Thong M., Mols F., Oerlemans S., Kaptein A.A., van de Poll-Franse L. (2013) Illness perceptions in cancer survivors: what is the role of information provision?. Psycho-Oncology. 22: $490-498$

Inman D.M., Maxson P.M., Johnson K.M., Myers R.P., Holland D.E. (2011) The Impact of Followup Educational Telephone Calls on Patients after Radical Prostatectomy. Urologic Nursing. 31(2): 83-91. 
Jefford M., Lotfi-Jam K., Baravelli C., Grogan S., Rogers M., Krishnasamy M., Pezaro C., Milne D., Aranda S., King D., Shaw B., Schofield P. (2011) Development and pilot testing of a nurse-led posttreatment support package for bowel cancer survivors. Cancer Nursing. 34(3): E1-10.

Jensen B.T., Kristensen S., Christensen S., Borre M. (2011) Efficacy of tele-nursing consultations in rehabilitation after radical prostatectomy: a randomised controlled trial study. Urological Nursing. 5(3): 123-130.

Kaunonen M. (2000) Support for a Family in Grief. Acta Universitatis Tamperensis 731. Tampere, Finland: Tampere University.

Kelly D. (1999) Ovarian Cancer Treatment: the Benefit of Patient Telephone Follow-up Post Chemotherapy. Canadian Oncology Nursing Journal. 9(4): 175-178.

Kilbourn K.M., Anderson D., Costenaro A., Lusczakoski K., Borrayo E., Raben D. (2013) Feasibility of EASE: a psychosocial program to improve symptom management in head and neck cancer patients. Supportive Care in Cancer. 21(1): 191-200.

Kim S.H., Shin M.S., Lee H.S., Lee E.S., Ro J.S., Kang H.S., Kim S.W., Lee W.H., Kim H.S., Kim C.J., Kim J., Yun Y.H. (2011) Randomized pilot test of a simultaneous stage-matched exercise and diet intervention for breast cancer survivors. Oncology Nursing Forum. 38(2):E97-106.

Kimman M.L., Dellaert B.G.C., Boersma L.J., Lambin P., Dirksen C.D. (2010a) Follow-up after treatment for breast cancer: One strategy fits all? An investigation of patient preferences using a discrete choice experiment. Acta Oncologica. 429: 328-337.

Kimman M.L., Bloebaum M.M., Dirksen C.D., Houben R.M., Lambin P., Boersma L.J. (2010b) Patient satisfaction with nurse-led telephone follow-up after curative treatment for breast cancer. BMC Cancer. 10:174.

Kitson A., Marshall A., Bassett K., Zeitz K. (2013) What are the core elements of patient-centred care? A narrative review and synthesis of the literature from health policy, medicine and nursing. Journal of Advanced Nursing. 69(1): 4-15. 
Kleiboer A., Gowing K., Holm Hansen C., Hibberd C., Hodges L., Walker J., Thekkumpurath P., O'Connor M., Murray G., Sharpe M. (2010) Monitoring symptoms at home: what methods would cancer patients be comfortable using?. Quality of Life Research. 19(7): 965-968.

Krumholz H.M,. Amatruda J., Smith G.L., Mattera J.A., Roumanis S.A., Radford M.J., Crombie P., Vaccarino V. (2002) Randomized trial of an education and support intervention to prevent readmission of patients with heart failure. Journal of the American College of Cardiolgy. 39(1): 839.

Leahy M., Krishnasamy M., Herschtal A., Bressel M., Dryden T., Tai K.H., Foroudi F. (2013) Satisfaction with nurse-led telephone follow up for low to intermediate risk prostate cancer patients treated with radical radiotherapy. A comparative study. European Journal of Oncology Nursing. 17(2): 162-9.

Locker D., Dunt D. (1978) Theoretical and methodological issues in sociological studies of consumer satisfaction with medical care. Social Science \& Medicine. 12:283-292.

Livingston P.M., Craike M.J., White V.M., Hordern A.J., Jefford M., Botti M.A., Lethborg C., Oldroyd J.C. (2010) A nurse-assisted screening and referral program for depression among survivors of colorectal cancer: feasibility study. Medical Journal of Australia. 193(5 Suppl): S83-7.

Macartney D., Stacey M., Carley M., Harrison M.B. (2012) Priorities, barriers and facilitators for remote telephone support of cancer symptoms: a survey of Canadian oncology nurses. Canadian Oncology Journal. 22(4): 135-144.

Marcus A.C., Cella D., Sedlacek S., Crawford D., Crane L., Garrett K., Quigel C., Gonin R. (1993) Psychosocial Counseling of Cancer Patients By Telephone: A Brief Note on Patient Acceptance of an Outcall Strategy. Psycho-oncology. 2: 209-214

Marcus A.C., Garrett K.M., Cella D., Wenzel L., Brady M.J., Fairclough D., Pate-Willig M., Barnes D., Emsbo S.P., Kluhsman B.C., Crane L., Sedlacek S., Flynn P.J. (2010) Can telephone counseling post-treatment improve psychosocial outcomes among early stage breast cancer survivors? Psychooncology. 19(9): 923-32. 
Martin L.A., Nelson E.C., Lloyd R.C., Nolan T.W. (2007) Whole System Measures [IHI innovation Series White Paper]. Cambridge, MA, Institute for Healthcare Improvement. [online] Available at: $<$ http://IHI.org $>$ [Accessed 5 May 2013].

Mistiaen P., Poot E. (2006) Telephone follow-up, initiated by a hospital-based health professional for postdischarge problems in patients discharged from hospital to home. Cochrane Database of Systematic Reviews. 18(4): CD004510.

Mordenti P., Capuano D.L., Zanlari L., Achilli R., Galli M.L., Marazzi E., Gandolfi S., Granelli B., Terzoni D., Civardi G., Cavanna L. (2013) Reduction of fear and acute toxicity from chemotherapy with a telephone call after the first cycle. Journal of Pain and Symptom Management. 46(2): e6-9.

Munro A.J., Shaw T., Clarke L., Becker L., Greenwood S. (1994) A Randomized Study of Telephone Contact Following Completion of Radiotherapy. Clinical Oncology. 6:242-244

Mustafa M., Carson-Stevens A., Gillespie D., Edwards A.G. (2013) Psychological interventions for women with metastatic breast cancer. Cochrane Database of Systematic Reviews. 6: CD004253.

Parahoo K., McDonough S., McCaughan E., Noyes J., Semple C., Halstead E.J., Neuberger M.M., Dahm P. (2013) Psychosocial interventions for men with prostate cancer. Cochrane Database of Systematic Reviews. 12: CD008529.

Pare G., Mirou J., Sicotte C. (2007) Systematic review of home telemonitoring for chronic diseases. The evidence base. Journal of the America Medical Informatics Association. 14: 269-277.

Reese J.B., Porter L.S., Somers T.J., Keefe F.J. (2012) Pilot feasibility study of a telephone-based couples intervention for physical intimacy and sexual concerns in colorectal cancer. Journal of Sex and Marital Therapy. 38(5):402-17.

Reese J.B., Porter L.S., Regan K.R., Keefe F.J., Azad N.S., Diaz L.A. Jr, Herman J.M., Haythornthwaite J.A. (2014) A randomized pilot trial of a telephone-based couples intervention for physical intimacy and sexual concerns in colorectal cancer. Psychooncology. 223(9):1005-13. 
Rueda J.R., Solà I., Pascual A., Subirana Casacuberta M. (2011) Non-invasive interventions for improving well-being and quality of life in patients with lung cancer. Cochrane Database of Systematic Reviews. 9: CD004282.

Salonen P., Tarkka M., Pellokumpu-Lehtinen P.L., Astedt-Kurki P., Luukkaala P., Kaunonen M. (2009) Telephone Intervention and Quality of Life in Patients With Breast Cancer. Cancer Nursing. 32(3):177- 190

Sandgren A.K., McCaul K.D., King B., O'Donnell S., Foreman G. (2000) Telephone therapy for patients with breast cancer. Oncology Nursing Forum. 27(4):683-8.

Sardell S., Sharpe G., Ashley S., Guerrero D., Brada M. (2000) Evaluation of a nurse-led telephone clinic in the follow-up of patients with malignant glioma. Clinical Oncology. 12(1): 36-41.

Scott D.A., Mills M., Black A., Cantwell M., Campbell A., Cardwell C.R., Porter S., Donnolley M. (2013) Multidimensional rehabilitation programmes for adult cancer survivors. Cochrane Database of Systematic Reviews. 3: CD007730.

Smithies M., Bettger-Hahn M., Forchuk C., Brackstone M. (2009) Telephone contact intervention in women undergoing treatment for breast cancer. Canadian Oncology Nursing Journal. 19(3): 122-8.

Stacey D., Bakker D., Green E., Zanchetta M., Conlon M. (2012) Ambulatory oncology nursing telephone services: a provincial survey. Canadian Oncology Nursing Journal. 17: 1-5.

Steginga S.K., Ferguson M., Clutton S., Gardiner R.A., Nicol D. (2008) Early decision and psychosocial support intervention for men with localised prostate cancer: an integrated approach. Supportive Care in Cancer. 16(7): 821-9.

Taylor S., Harley C., Campbell L.J., Bingham L., Podmore E.J., Newsham A.C., Shelby P.J., Brown J.M., Velikova G. (2011) Discussion of emotional and social impact of cancer during outpatient oncology consultations. Psycho-Oncology 20: 242-251.

Van Tiel F., Harbers M., Kessels A., Schouten H. (2005) Home care versus hospital care of patients 
with haematological malignancies and chemotherapy- induced cytopenia. Annals of Oncology. 16(2): 195-205.

Wilmoth M.C., Tulman L., Coleman E.A., Stewart C.B., Samarel N. (2006) Women's perceptions of the effectiveness of telephone support and education on their adjustment to breast cancer during the year following diagnosis. Oncology Nursing Forum. 33(1): 138-44.

Young J., Harrison J., Solomon M., Butow P., Dennis R., Robson D., Auld S. (2010) Development and feasibility assessment of telephone-delivered supportive care to improve outcomes for patients with colorectal cancer: pilot study of the CONNECT intervention. Supportive Care in Cancer. 18(4): 461-70.

Young J.M., Butow P.N., Walsh J., Durcinoska I., Dobbins T.A., Rodwell L., Harrison J.D., White K., Gilmore A., Hodge B., Hicks H., Smith S., O'Connor G., Byrne C.M., Meagher A.P., Jancewicz S., Sutherland A., Ctercteko G., Pathma-Nathan N., Curtin A., Townend D., Abraham N.S., Longfield G., Rangiah D., Young C.J., Eyers A., Lee P., Fisher D., Solomon M.J. (2013) Multicenter randomized trial of centralized nurse-led telephone-based care coordination to improve outcomes after surgical resection for colorectal cancer: the CONNECT intervention. Journal of Clinical Oncology. 31(28):3585-91.

Zhang J.E., Wong F.K., You L.M., Zheng M.C., Li Q., Zhang B.Y., Huang M.R., Ye X.M., Liang M.J., Liu J.L. (2013) Effects of enterostomal nurse telephone follow-up on postoperative adjustment of discharged colostomy patients. Cancer Nursing. 36(6):419-28.

Zheng M.C., Zhang J.E., Qin H.Y., Fang Y.J., Wu X.J. (2013) Telephone follow-up for patients returning home with colostomies: views and experiences of patients and enterostomal nurses. European Journal of Oncology Nursing. 17(2): 184-9. 


\section{Page 33 of 53}

1

2

3

4

5

6

7

8

10

11

12

13

14

15

16

17

18

19

20

21

22

23

24

25

26

27

28

29

30

31

32

33

34

35

36

37

38

39

40

41

42

43

44

45

46

47

48

49

50

51

52

53

54

55

56

57

58

59

60

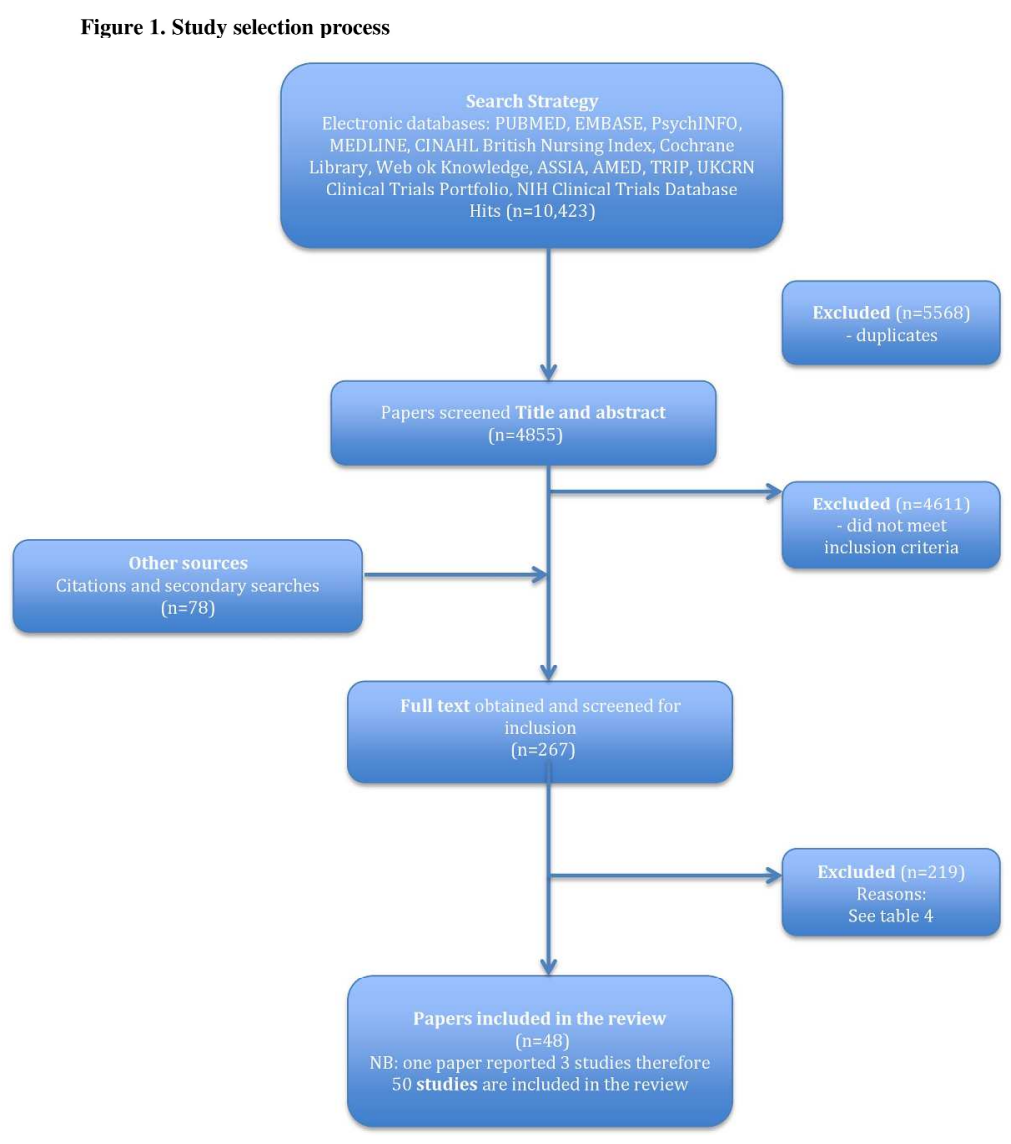

Figure 1 Study Selection Process

$209 \times 297 \mathrm{~mm}(300 \times 300$ DPI)

European Journal of Cancer Care 
Table 1 - Study Inclusion / Exclusion criteria

\begin{tabular}{|c|c|c|}
\hline \multicolumn{2}{|c|}{ Inclusion Criteria } & Exclusion criteria \\
\hline $\begin{array}{l}\text { Participant } \\
\text { related }\end{array}$ & $\begin{array}{l}\geq 75 \% \text { of patients (any gender) aged } \geq 18 \text { years old } \\
\text { (no upper age limit) } \\
\text { Clinical diagnosis of cancer (any type) }\end{array}$ & $\begin{array}{l}\text { Support not instigated } \\
\text { by the service } \\
\text { provider i.e. where } \\
\text { participants call in to } \\
\text { a helpline. }\end{array}$ \\
\hline $\begin{array}{l}\text { Treatment } \\
\text { related }\end{array}$ & $\begin{array}{l}\text { Cancer treatment is defined as surgery, } \\
\text { chemotherapy, radiotherapy, immunotherapy or } \\
\text { biological therapies, hormonal therapies, radio- } \\
\text { immunotherapy, stem cell transplant, bone marrow } \\
\text { transplant, photodynamic therapy or } \\
\text { radiofrequency ablation. } \\
\text { Studies evaluating telephone interventions during } \\
\text { or post- cancer treatment only }\end{array}$ & $\begin{array}{l}\text { Telephone } \\
\text { intervention not } \\
\text { related to cancer } \\
\text { treatment (i.e. } \\
\text { smoking cessation). } \\
\text { Use of automated } \\
\text { voice response } \\
\text { systems (not personal } \\
\text { interactions) }\end{array}$ \\
\hline $\begin{array}{l}\text { Intervention } \\
\text { related }\end{array}$ & $\begin{array}{l}\text { Telephone intervention providing support for } \\
\text { physical or psychosocial issues related to cancer or } \\
\text { cancer treatment. For the purpose of this review, } \\
\text { support is defined as psychological, social, } \\
\text { emotional, information support or monitoring. } \\
\text { Delivered by any qualified healthcare professional } \\
\text { At least one telephone call initiated by a healthcare } \\
\text { professional who is specified to be individually } \\
\text { involved in the treatment/ care of the patient }\end{array}$ & 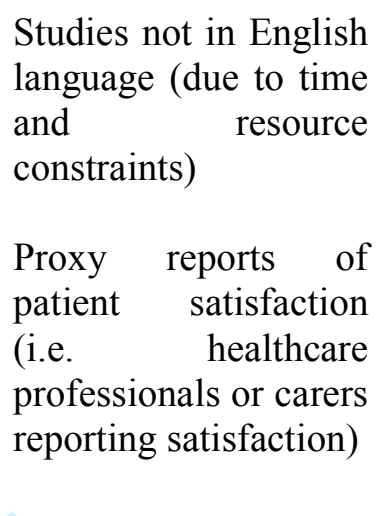 \\
\hline $\begin{array}{l}\text { Type of } \\
\text { study }\end{array}$ & $\begin{array}{l}\text { Published studies providing data relating to any of } \\
\text { the outcome concepts will be included (including } \\
\text { RCT's, controlled and uncontrolled studies, } \\
\text { qualitative studies, theses, conference proceedings, } \\
\text { but not individual case studies) }\end{array}$ & \\
\hline $\begin{array}{l}\text { Type of } \\
\text { outcomes }\end{array}$ & $\begin{array}{l}\text { Perceptions of patients as service users } \\
\text { Reporting acceptability of telephone as a means of } \\
\text { support / intervention delivery in any part of the } \\
\text { document. For the purpose of this review, } \\
\text { acceptability is defined as acceptance, } \\
\text { acceptability, satisfaction with, opinions, beliefs, } \\
\text { views, attitudes, impressions, experience or } \\
\text { perceptions of patients having participated in a } \\
\text { telephone intervention. }\end{array}$ & \\
\hline
\end{tabular}


Table 2 - Databases searched

\begin{tabular}{|l|}
\hline Database \\
\hline PUBMED \\
\hline EMBASE (1974 to present) \\
\hline PsychINFO (1989 to present) \\
\hline MEDLINE (1948 to present) \\
\hline CINAHL (1981 to present) \\
\hline British Nursing Index (1985 to present) \\
\hline Cochrane Library \\
\hline Web of Knowledge \\
\hline ASSIA (Applied Social Sciences Index and Abstracts) \\
\hline AMED (Allied and Complementary Medicine Database - includes palliative care) \\
\hline TRIP (Turning Research into Practice) Database \\
\hline UKCRN clinical trials portfolio \\
\hline NIH Clinical trials database \\
\hline
\end{tabular}




\section{Page 36 of 53}


Table 3a Search Terms for the Systematic Review

\begin{tabular}{|c|c|c|}
\hline Search words & Search Term & Terms covered \\
\hline \multicolumn{3}{|c|}{ DIAGNOSTIC TERMS } \\
\hline Cancer & $\begin{array}{l}\text { cancer* } \\
\text { neoplasm* } \\
\text { carcinoma* } \\
\text { tumour* } \\
\text { adenocarcinoma* } \\
\text { tumor* } \\
\text { malignan* } \\
\text { oncolog* }\end{array}$ & $\begin{array}{l}\text { Cancer/ cancerous/ cancers } \\
\text { Neoplasm/ neoplasms } \\
\text { Carcinoma/ carcinomas } \\
\text { Tumour/ tumours } \\
\text { Adenocarcinoma/ adenocarcinomas } \\
\text { Tumor/ tumors } \\
\text { Malignant/ malignancy } \\
\text { Oncology/ oncological }\end{array}$ \\
\hline \multicolumn{3}{|c|}{ TREATMENT TERMS } \\
\hline Treatment & $\begin{array}{l}\text { surg* } \\
\text { *ectomy } \\
\text { chemotherap* } \\
\text { radiotherap* } \\
\text { immunotherap* } \\
\text { biological AND therap* } \\
\text { hormon* AND therap* } \\
\text { radioimmuno* AND therap* } \\
\text { stem AND cell AND transplant* } \\
\text { bone AND marrow AND transplant* } \\
\text { hematopoietic AND stem AND cell AND transplant } \\
\text { photodynamic AND therap* } \\
\text { radiofrequency AND ablation } \\
\text { treatment }\end{array}$ & $\begin{array}{l}\text { Surgery/ surgical } \\
\text { Lumpectomy/prostatectomy.... } \\
\text { Chemotherapy/ chemotherapies/ } \\
\text { chemotherapeutic } \\
\text { Radiotherapy/ radiotherapies } \\
\text { Immunotherapy/ immunotherapies } \\
\text { biological therapy/ therapies } \\
\text { hormone/ hormonal AND therapy/therapies } \\
\text { radioimmunotherapy } \\
\text { radioimmunotherapies } \\
\text { stem cell transplant/ stem cell transplantation } \\
\text { bone marrow transplant/ bone marrow } \\
\text { transplantation } \\
\text { hematopoietic stem cell transplant/ } \\
\text { haematopoetic stem cell transplantation } \\
\text { photodynamic therapy/ therapies } \\
\text { radiofrequency ablation } \\
\text { treatment }\end{array}$ \\
\hline \multicolumn{3}{|c|}{ INTERVENTION TERMS } \\
\hline Intervention & $\begin{array}{l}\text { phone / telephone / mobile phone / mobile telephone } \\
\text { remote / non face-to-face / distance }\end{array}$ & \\
\hline \multicolumn{3}{|c|}{ SUPPORT TERMS } \\
\hline Support & $\begin{array}{l}\text { monitor* } \\
\text { follow-up } \\
\text { follow AND up } \\
\text { information* AND support } \\
\text { social AND support } \\
\text { psych* AND support } \\
\text { emotion* AND support }\end{array}$ & $\begin{array}{l}\text { Monitor/ monitored/ monitoring } \\
\text { Information } \\
\text { Psychological/ psychosocial } \\
\text { Emotion/ emotions/ emotional }\end{array}$ \\
\hline \multicolumn{3}{|c|}{ ACCEPTIBILITY TERMS } \\
\hline $\begin{array}{l}\text { Acceptability / } \\
\text { satisfaction }\end{array}$ & $\begin{array}{l}\text { accepta* } \\
\text { adequa* } \\
\text { satisf* } \\
\text { opinion* } \\
\text { belief* } \\
\text { view* } \\
\text { attitude* } \\
\text { impression* } \\
\text { experience* } \\
\text { perception* } \\
\text { uptake } \\
\text { barrier* } \\
\text { valu* }\end{array}$ & $\begin{array}{l}\text { Acceptable/ acceptability/ acceptance } \\
\text { Adequate/ adequacy/ adequateness } \\
\text { satisfaction / satisfy/ satisfied/ satisfactory } \\
\text { opinion/ opinions } \\
\text { belief/ beliefs } \\
\text { view/ views } \\
\text { attitude/ attitudes } \\
\text { impression/ impressions } \\
\text { experience/ experiences } \\
\text { perception/perceptions } \\
\text { uptake } \\
\text { barrier/ barriers } \\
\text { value/ values }\end{array}$ \\
\hline
\end{tabular}


Table 3b Search Terms used for specific databases

\begin{tabular}{|l|l|}
\hline Database & Search words \\
\hline TRIP terms & $\begin{array}{l}\text { phone OR telephone OR mobile OR remote OR distance } \\
\text { AND Cancer }\end{array}$ \\
\hline $\begin{array}{l}\text { UKCRN clinical } \\
\text { trials portfolio }\end{array}$ & $\begin{array}{l}\text { Type - Cancer } \\
\text { Any of the following - phone OR telephone OR mobile OR remote OR non face-to-face OR distance }\end{array}$ \\
\hline $\begin{array}{l}\text { NIH Clinical trials } \\
\text { database }\end{array}$ & $\begin{array}{l}\text { Cancer } \\
\text { AND Phone OR telephone OR mobile } \\
\text { AND Adult or senior }\end{array}$ \\
\hline
\end{tabular}


Table 4-Summary of excluded papers

\begin{tabular}{|l|l|l|}
\hline Reason for rejection & $\begin{array}{l}\text { Number of } \\
\text { papers from } \mathbf{1}^{\text {st }} \\
\text { search }\end{array}$ & $\begin{array}{l}\text { Number of } \\
\text { papers from } \mathbf{2}^{\text {nd }} \\
\text { search }\end{array}$ \\
\hline $\begin{array}{l}\text { Lack of information to confirm inclusion e.g. } \\
\text { conference proceedings, no further information/ } \\
\text { data available from authors }\end{array}$ & 12 & 2 \\
\hline $\begin{array}{l}\text { Failed to meet participant criteria e.g. }<75 \% \\
\text { receiving treatment, no cancer diagnosis, } \\
\text { participants not patients }\end{array}$ & 14 & 8 \\
\hline $\begin{array}{l}\text { Failed to meet intervention criteria e.g. patient } \\
\text { initiated calls, not HCP delivered, no telephone } \\
\text { intervention, videophone, telemedicine, telephone } \\
\text { for data collection not intervention }\end{array}$ & 44 & 19 \\
\hline $\begin{array}{l}\text { Failed to meet outcome criteria e.g. not patient } \\
\text { perceptions, not satisfaction data, no results }\end{array}$ & 54 & 27 \\
\hline $\begin{array}{l}\text { Other e.g. not primary research studies, data in } \\
\text { another paper }\end{array}$ & 34 & 5 \\
\hline \multicolumn{2}{|l|}{} & $\mathbf{6 1}$ \\
\hline Total number of papers rejected & $\mathbf{1 5 8}$ \\
\hline
\end{tabular}

HCP - Healthcare Professional 
Table 5 Overall Study Quality

Tabulated data from study quality assessment of bias in RCT's and non-RCT's providing quantitative acceptability / satisfaction data from all cohorts (based on Cochrane Collaboration Risk Bias of Assessment Tool for RCT's and for nRCT's (Higgins \& Green, 2011))

\begin{tabular}{|c|c|c|c|c|c|c|c|c|}
\hline First Author / Date & 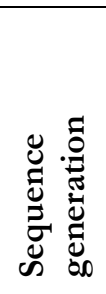 & 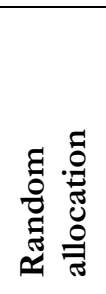 & 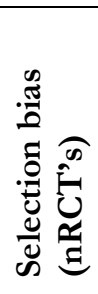 & 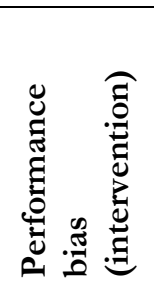 & 悉 & 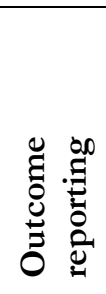 & 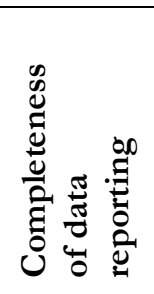 & 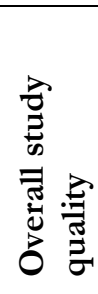 \\
\hline \multicolumn{9}{|l|}{ RCT's } \\
\hline Badger et al, 2013 & $\mathrm{H}$ & $\mathrm{H}$ & $\mathrm{N} / \mathrm{A}$ & $\mathrm{L}$ & $\mathrm{H}$ & $\mathrm{H}$ & $\mathrm{H}$ & $\mathrm{L}$ \\
\hline Beaver et al, 2009 & $\mathrm{~L}$ & $\mathrm{~L}$ & $\mathrm{~N} / \mathrm{A}$ & $\mathrm{L}$ & $\mathrm{L}$ & $\mathrm{L}$ & $\mathrm{L}$ & $\mathrm{H}$ \\
\hline Beaver et al, 2012 & $\mathrm{~L}$ & $\mathrm{~L}$ & $\mathrm{~N} / \mathrm{A}$ & $\mathrm{H}$ & $\mathrm{L}$ & $\mathrm{H}$ & $\mathrm{L}$ & $\mathrm{M}$ \\
\hline Hegel et al, 2011 & $\mathrm{H}$ & $\mathrm{H}$ & $\mathrm{N} / \mathrm{A}$ & $\mathrm{L}$ & $\mathrm{L}$ & $\mathrm{H}$ & $\mathrm{H}$ & $\mathrm{M}$ \\
\hline $\begin{array}{l}\text { Heidrich et al, } 2009 \\
\text { Pilot Study } 1\end{array}$ & $\mathrm{H}$ & $\mathrm{H}$ & $\mathrm{N} / \mathrm{A}$ & $\mathrm{L}$ & $\mathrm{L}$ & $\mathrm{H}$ & $\mathrm{U}$ & $\mathrm{M}$ \\
\hline $\begin{array}{l}\text { Heidrich et al, } 2009 \\
\text { Pilot Study } 2\end{array}$ & $\mathrm{H}$ & $\mathrm{H}$ & $\mathrm{N} / \mathrm{A}$ & $\mathrm{L}$ & $\mathrm{L}$ & $\mathrm{H}$ & $\mathrm{U}$ & $\mathrm{M}$ \\
\hline Kimman et al, 2010 & $\mathrm{~L}$ & $\mathrm{~L}$ & $\mathrm{~N} / \mathrm{A}$ & $\mathrm{L}$ & $\mathrm{H}$ & $\mathrm{L}$ & $\mathrm{L}$ & $\mathrm{H}$ \\
\hline Munro et al, 1994 & $\mathrm{U}$ & $\mathrm{U}$ & $\mathrm{N} / \mathrm{A}$ & $\mathrm{L}$ & $\mathrm{L}$ & $\mathrm{L}$ & $\mathrm{L}$ & $\mathrm{M}$ \\
\hline \multicolumn{9}{|l|}{ Non-RCT's } \\
\hline Hafiji et al, 2012 & $\mathrm{~N} / \mathrm{A}$ & $\mathrm{N} / \mathrm{A}$ & $\mathrm{H}$ & $\mathrm{L}$ & $\mathrm{U}$ & $\mathrm{U}$ & $\mathrm{U}$ & $\mathrm{L}$ \\
\hline Leahy et al, 2013 & $\mathrm{~N} / \mathrm{A}$ & $\mathrm{N} / \mathrm{A}$ & $\mathrm{U}$ & $\mathrm{L}$ & $\mathrm{H}$ & $\mathrm{L}$ & $\mathrm{H}$ & $\mathrm{M}$ \\
\hline
\end{tabular}

N/A - Not applicable, H - High, L - Low, M - Medium, U - Unclear 
Tabulated data from study quality assessment of bias in RCT's, non-RCT's and single group studies providing quantitative acceptability / satisfaction data from the intervention group only (based on Cochrane Collaboration Risk Bias of Assessment Tool for nRCT's (Higgins \& Green, 2011))

\begin{tabular}{|c|c|c|c|c|c|c|}
\hline First Author / Date & 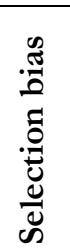 & 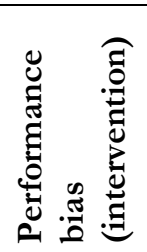 & 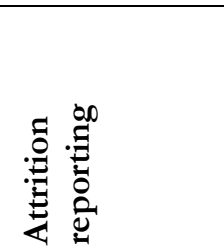 & 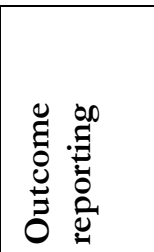 & 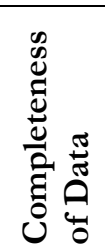 & 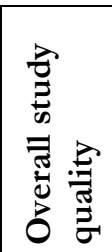 \\
\hline Anderson, 2010 & $\mathrm{H}$ & $\mathrm{L}$ & $\mathrm{L}$ & $\mathrm{H}$ & $\mathrm{H}$ & M \\
\hline Barsevick et al, 2002 & $\mathrm{H}$ & $\mathrm{L}$ & $\mathrm{U}$ & $\mathrm{H}$ & $\mathrm{H}$ & $\mathrm{L}$ \\
\hline Booker et al, 2004 & $\mathrm{H}$ & $\mathrm{U}$ & $\mathrm{L}$ & $\mathrm{U}$ & $\mathrm{U}$ & $\mathrm{L}$ \\
\hline Cimprich et al, 2005 & $\mathrm{~L}$ & $\mathrm{~L}$ & $\mathrm{~L}$ & $\mathrm{U}$ & $\mathrm{U}$ & $\mathrm{M}$ \\
\hline Cirillo et al, 2014 & $\mathrm{U}$ & $\mathrm{U}$ & $\mathrm{U}$ & $\mathrm{H}$ & $\mathrm{H}$ & $\mathrm{L}$ \\
\hline Cox et al, 2005 & $\mathrm{H}$ & $\mathrm{L}$ & $\mathrm{U}$ & $\mathrm{H}$ & $\mathrm{H}$ & $\mathrm{L}$ \\
\hline Cox et al, 2008 & $\mathrm{H}$ & $\mathrm{L}$ & $\mathrm{U}$ & $\mathrm{L}$ & $\mathrm{L}$ & $\mathrm{M}$ \\
\hline Craven et al, 2013 & $\mathrm{H}$ & $\mathrm{L}$ & $\mathrm{L}$ & $\mathrm{U}$ & $\mathrm{U}$ & $\mathrm{L}$ \\
\hline Delaney et al, 2009 & $\mathrm{H}$ & $\mathrm{L}$ & $\mathrm{L}$ & $\mathrm{H}$ & $\mathrm{L}$ & $\mathrm{M}$ \\
\hline Garrett et al, 2013 & $\mathrm{H}$ & $\mathrm{U}$ & $\mathrm{H}$ & $\mathrm{U}$ & $\mathrm{U}$ & $\mathrm{L}$ \\
\hline $\begin{array}{l}\text { Hagopian \& } \\
\text { Rubenstein, } 1990\end{array}$ & $\mathrm{H}$ & $\mathrm{L}$ & $\mathrm{U}$ & $\mathrm{H}$ & $\mathrm{H}$ & $\mathrm{L}$ \\
\hline $\begin{array}{l}\text { Heidrich et al, } 2009 \\
\text { Pilot Study } 3\end{array}$ & $\mathrm{H}$ & $\mathrm{L}$ & $\mathrm{U}$ & $\mathrm{H}$ & $\mathrm{H}$ & $\mathrm{L}$ \\
\hline Inman et al, 2011 & $\mathrm{U}$ & $\mathrm{L}$ & $\mathrm{L}$ & $\mathrm{U}$ & $\mathrm{L}$ & $\mathrm{M}$ \\
\hline Jensen et al, 2011 & $\mathrm{U}$ & $\mathrm{U}$ & $\mathrm{L}$ & $\mathrm{L}$ & $\mathrm{L}$ & $\mathrm{M}$ \\
\hline Kelly, 1999 & $\mathrm{H}$ & $\mathrm{L}$ & $\mathrm{H}$ & $\mathrm{H}$ & $\mathrm{H}$ & $\mathrm{L}$ \\
\hline Kilbourn et al, 2013 & $\mathrm{H}$ & $\mathrm{L}$ & $\mathrm{U}$ & $\mathrm{L}$ & $\mathrm{L}$ & $\mathrm{M}$ \\
\hline Kim et al, 2011 & $\mathrm{~L}$ & $\mathrm{~L}$ & $\mathrm{~L}$ & $\mathrm{H}$ & $\mathrm{L}$ & $\mathrm{M}$ \\
\hline Livingston et al, 2010 & $\mathrm{H}$ & $\mathrm{L}$ & $\mathrm{L}$ & $\mathrm{L}$ & $\mathrm{U}$ & $\mathrm{M}$ \\
\hline Marcus et al, 1993 & $\mathrm{H}$ & $\mathrm{H}$ & $\mathrm{L}$ & $\mathrm{U}$ & $\mathrm{U}$ & $\mathrm{L}$ \\
\hline Marcus et al, 2010 & $\mathrm{H}$ & $\mathrm{L}$ & $\mathrm{U}$ & $\mathrm{L}$ & $\mathrm{L}$ & $\mathrm{M}$ \\
\hline Mordenti et al, 2013 & $\mathrm{H}$ & $\mathrm{H}$ & 8 & $\mathrm{~L}$ & $\mathrm{~L}$ & $\mathrm{~L}$ \\
\hline Reese et al, 2012 & $\mathrm{H}$ & $\mathrm{L}$ & $\mathrm{L}$ & $\mathrm{L}$ & $\mathrm{L}$ & $\mathrm{M}$ \\
\hline Reese et al, 2014 & $\mathrm{U}$ & $\mathrm{L}$ & $\mathrm{L}$ & $\mathrm{H}$ & $\mathrm{H}$ & M \\
\hline Salonen et al, 2009 & $\mathrm{H}$ & $\mathrm{H}$ & $\mathrm{L}$ & $\mathrm{U}$ & $\mathrm{L}$ & $\mathrm{M}$ \\
\hline Sandgren et al, 2000 & $\mathrm{U}$ & $\mathrm{L}$ & $\mathrm{U}$ & $\mathrm{L}$ & $\mathrm{L}$ & $\mathrm{M}$ \\
\hline Sardell et al, 2000 & $\mathrm{H}$ & $\mathrm{L}$ & $\mathrm{L}$ & $\mathrm{U}$ & $\mathrm{H}$ & $\mathrm{M}$ \\
\hline Smithies et al, 2007 & $\mathrm{H}$ & $\mathrm{L}$ & $\mathrm{L}$ & $\mathrm{U}$ & $\mathrm{H}$ & $\mathrm{M}$ \\
\hline Steginga et al, 2007 & $\mathrm{H}$ & $\mathrm{L}$ & $\mathrm{L}$ & $\mathrm{H}$ & $\mathrm{H}$ & $\mathrm{M}$ \\
\hline Young et al, 2010 & $\mathrm{H}$ & $\mathrm{L}$ & $\mathrm{L}$ & $\mathrm{H}$ & $\mathrm{H}$ & $\mathrm{M}$ \\
\hline Young et al, 2013 & $\mathrm{~L}$ & $\mathrm{~L}$ & $\mathrm{~L}$ & $\mathrm{U}$ & $\mathrm{U}$ & $\mathrm{L}$ \\
\hline Zhang et al, 2013 & $\mathrm{~L}$ & $\mathrm{~L}$ & $\mathrm{U}$ & $\mathrm{L}$ & $\mathrm{L}$ & $\mathrm{H}$ \\
\hline
\end{tabular}

H - High, L - Low, M - Medium, U - Unclear 
Tabulated data from study quality bias assessment of studies providing high quality qualitative data (Critical Appraisal Skills Programme (CASP) tool (Critical Appraisal Skills Programme, 2013)

\begin{tabular}{|c|c|c|c|c|c|c|c|c|c|c|c|c|}
\hline $\begin{array}{l}\text { Author / } \\
\text { Date }\end{array}$ & 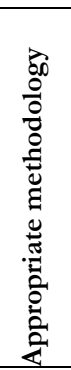 & 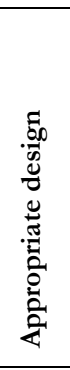 & 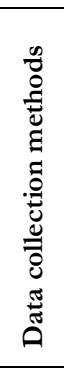 & 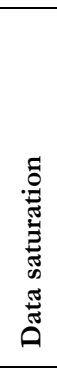 & 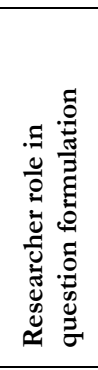 & 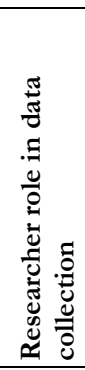 & $\begin{array}{l}\frac{\infty}{0} \\
\frac{0}{\pi} \\
\frac{2}{4}\end{array}$ & 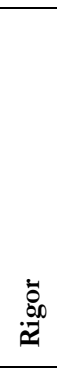 & 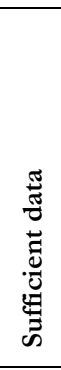 & 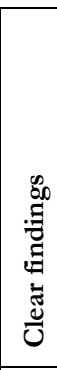 & 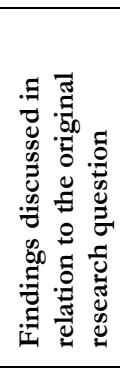 & 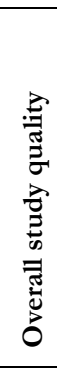 \\
\hline $\begin{array}{l}\text { Archer et } \\
\text { al, } 2014\end{array}$ & $\mathrm{~L}$ & $\mathrm{~L}$ & $\mathrm{~L}$ & $\mathrm{H}$ & $\mathrm{H}$ & $\mathrm{L}$ & $\mathrm{L}$ & $\mathrm{H}$ & $\mathrm{L}$ & $\mathrm{L}$ & $\mathrm{L}$ & $\mathrm{M}$ \\
\hline $\begin{array}{l}\text { Beaver et } \\
\text { al, 2010 }\end{array}$ & $\mathrm{L}$ & $\mathrm{L}$ & $\mathrm{L}$ & $\mathrm{U}$ & $\mathrm{U}$ & $\mathrm{U}$ & $\mathrm{L}$ & $\mathrm{L}$ & $\mathrm{L}$ & $\mathrm{L}$ & $\bar{L}$ & $\mathrm{H}$ \\
\hline $\begin{array}{l}\text { Campbell } \\
\text { et al, } 2007\end{array}$ & $\mathrm{~L}$ & $\mathrm{H}$ & $\mathrm{L}$ & $\mathrm{H}$ & $\mathrm{H}$ & $\mathrm{H}$ & $\mathrm{L}$ & $\mathrm{L}$ & $\mathrm{L}$ & $\mathrm{L}$ & $\mathrm{L}$ & $\mathrm{H}$ \\
\hline $\begin{array}{l}\text { Donnelly } \\
\text { et al, } 2013\end{array}$ & $\mathrm{~L}$ & $\mathrm{~L}$ & $\mathrm{~L}$ & $\mathrm{H}$ & $\mathrm{L}$ & $\mathrm{L}$ & $\mathrm{L}$ & $\mathrm{L}$ & $\mathrm{L}$ & $\mathrm{L}$ & $\bar{L}$ & $\mathrm{H}$ \\
\hline $\begin{array}{l}\text { Wilmoth } \\
\text { et al, } 2006\end{array}$ & $\mathrm{~L}$ & $\mathrm{~L}$ & $\mathrm{~L}$ & $\mathrm{H}$ & $\mathrm{L}$ & $\mathrm{H}$ & $\mathrm{L}$ & $\mathrm{L}$ & $\mathrm{L}$ & $\mathrm{L}$ & $\mathrm{L}$ & $\mathrm{H}$ \\
\hline $\begin{array}{l}\text { Zheng et } \\
\text { al, } 2013\end{array}$ & $\mathrm{~L}$ & $\mathrm{~L}$ & $\mathrm{~L}$ & $\mathrm{~L}$ & $\mathrm{H}$ & $\mathrm{H}$ & $\mathrm{L}$ & $\mathrm{L}$ & $\mathrm{L}$ & $\mathrm{L}$ & $\mathrm{L}$ & $\mathrm{H}$ \\
\hline
\end{tabular}

H - High, L - Low, M - Medium, U - Unclear 


\section{Table 6: Patient and Study Characteristics}

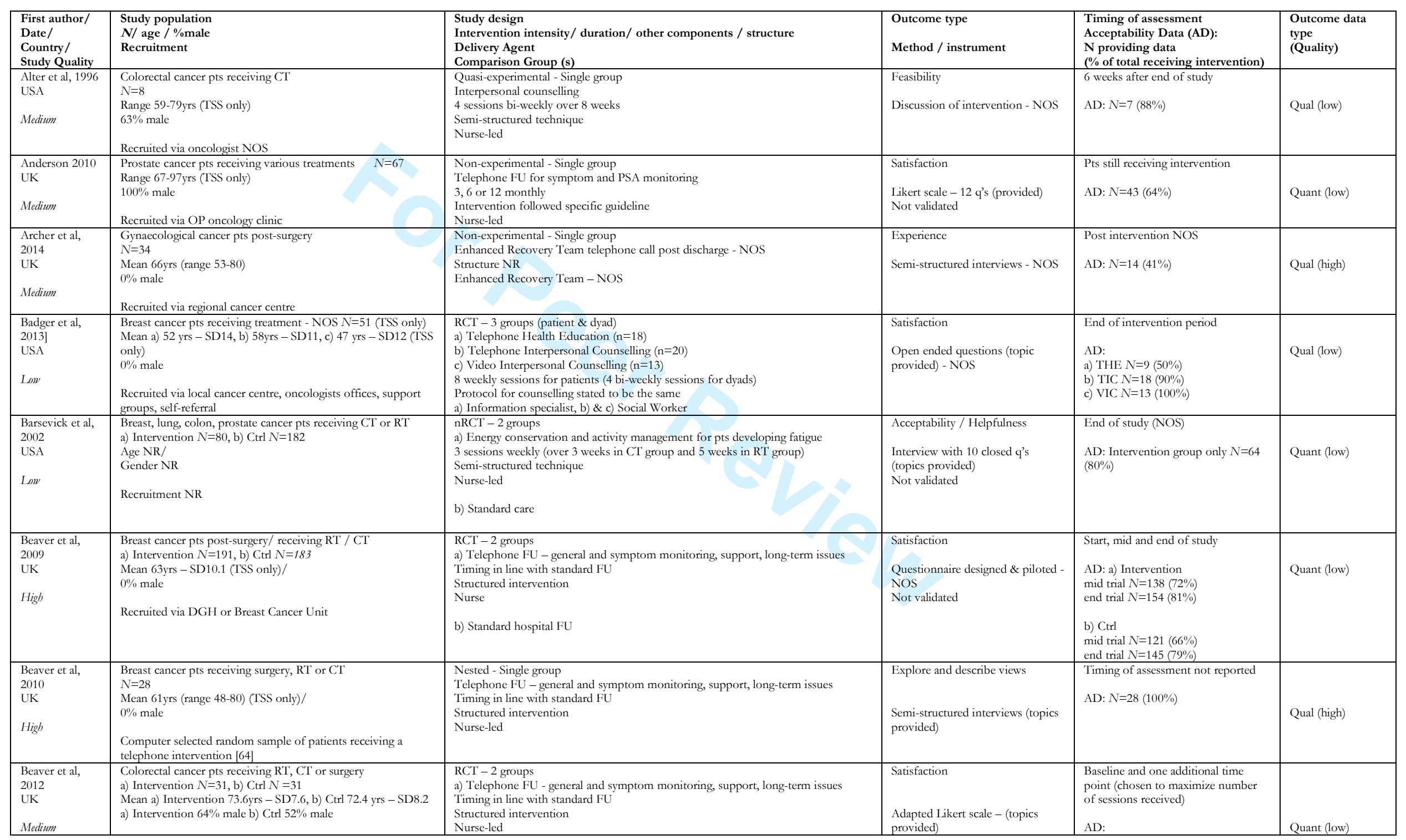


Page 44 of 53

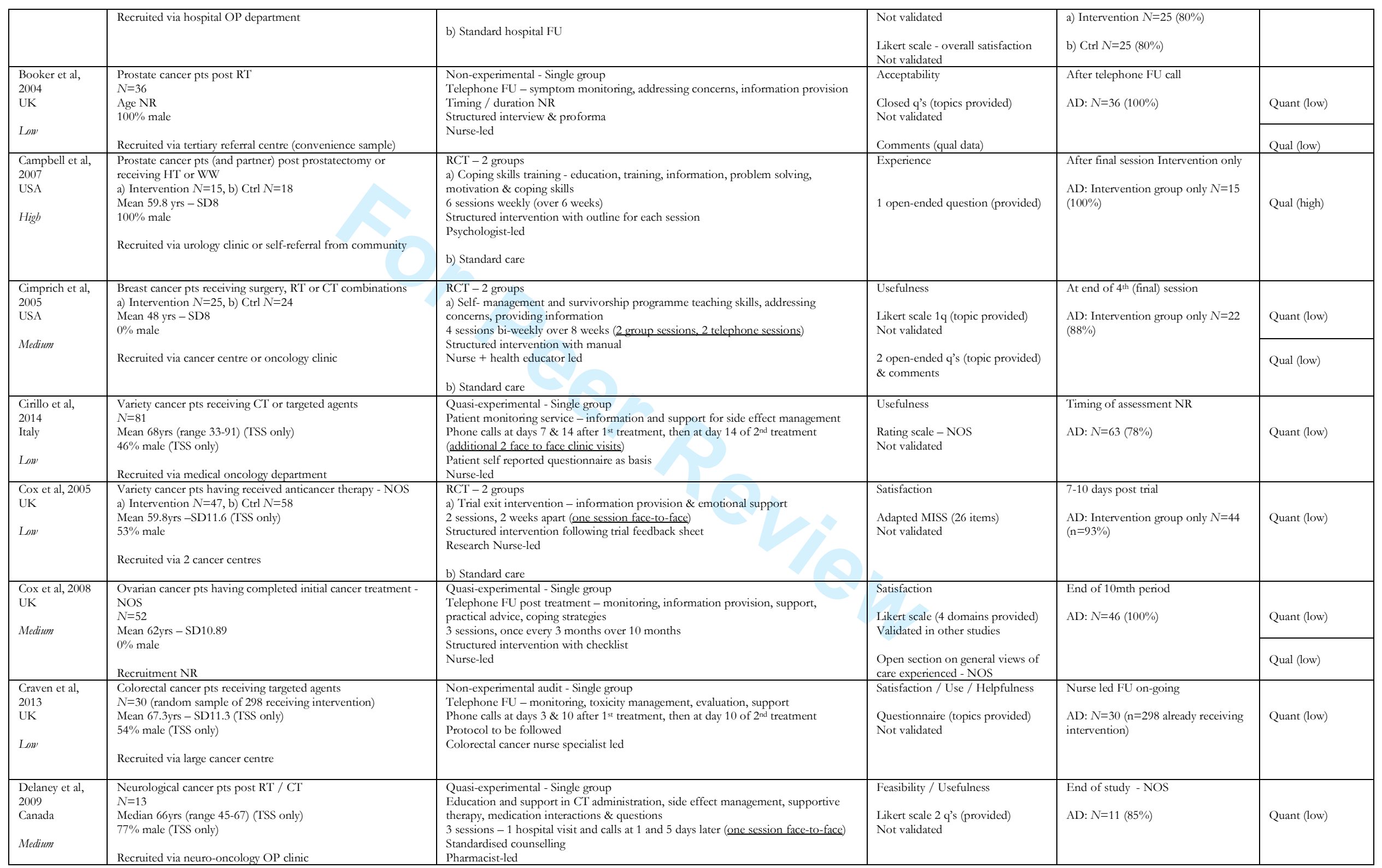

\section{European Journal of Cancer Care}




\begin{tabular}{|c|c|c|c|c|c|}
\hline $\begin{array}{l}\text { Dixon } 2010 \\
\text { Canada } \\
\text { Low }\end{array}$ & $\begin{array}{l}\text { Variety cancer pts post RT } \\
N=53 \\
\text { Mean } 69 \mathrm{yrs}(\mathrm{TSS} \text { only) } \\
63 \% \text { male (TSS only) } \\
\text { Recruitment NR } \\
\end{array}$ & $\begin{array}{l}\text { Quasi-experimental audit - Single group } \\
\text { Telephone FU post RT - monitoring of side effects / information provision } \\
2 \text { sessions } 1 \text { and } 4 \text { weeks post RT } \\
\text { Structured intervention (ESAS) } \\
\text { Radiation therapist-led }\end{array}$ & $\begin{array}{l}\text { Feedback/ satisfaction } \\
\text { Comments during telephone calls }\end{array}$ & $\begin{array}{l}\text { During intervention - NOS } \\
\mathrm{AD}: \mathrm{N}=38(72 \%)\end{array}$ & Qual (low) \\
\hline $\begin{array}{l}\text { Donnelly et al, } \\
2013 \\
\text { UK } \\
\text { High }\end{array}$ & $\begin{array}{l}\text { Gynaecological cancer pts having completed or receiving } \\
\text { treatment - NOS } \\
\text { (Patients having participated in RCT) } \\
N=31 \\
\text { Mean } 55 \text { yrs (range 38-78) } \\
0 \% \text { male } \\
\text { Recruited following invitation to all patients involved in RCT }\end{array}$ & $\begin{array}{l}\text { Nested - sample from } 2 \text { groups } \\
\text { a) Telephone contact - symptom checklist } \\
\text { b) Telephone contact + physical activity program - levels of activity, barriers, goals, } \\
\text { symptom checklist } \\
\text { Weekly telephone calls -NOS - over } 12 \text { weeks } \\
\text { NR - Telephone component } \\
\text { Physiotherapist - Activity Program }\end{array}$ & $\begin{array}{l}\text { Experiences } \\
\text { Focus groups - open ended } \\
\text { questions (topics provided) }\end{array}$ & $\begin{array}{l}\text { Timing of assessment NR } \\
\text { AD: } N=16(52 \%)\end{array}$ & Qual (high) \\
\hline $\begin{array}{l}\text { Garrett et al, } \\
2013 \\
\text { USA } \\
\text { Low }\end{array}$ & $\begin{array}{l}\text { Variety cancer pts receiving surgery, } \mathrm{CT} \text { or RT } \\
N=66 \\
\text { Range } 20-69 \mathrm{yrs} \\
48 \% \text { male } \\
\text { Recruited via oncology clinics and rural community cancer } \\
\text { centre }\end{array}$ & $\begin{array}{l}\text { Quasi-experimental - Single group } \\
\text { Cancer Survivor Telephone Education and Personal Support Program (C-STEPS) - } \\
\text { Choice to participate in either / both modules: Uncertainty \& Stress Management / } \\
\text { Healthy Diet \& Physical Exercise } \\
6 \text { weekly sessions } \\
\text { Semi-structured intervention following worksheet } \\
\text { Occupational Therapist led }\end{array}$ & $\begin{array}{l}\text { Satisfaction / Helpfulness } \\
\text { Likert scale questionnaire (topics } \\
\text { provided) } \\
\text { Not validated }\end{array}$ & $\begin{array}{l}\text { After completion of program - NOS } \\
\text { AD: } N=46(70 \%)\end{array}$ & Quant (low) \\
\hline $\begin{array}{l}\text { Hafiji et al, } \\
2012 \\
\text { New Zealand } \\
\text { (NZ) \& UK } \\
\text { Low }\end{array}$ & $\begin{array}{l}\text { Non melanoma skin cancer pts post-surgery } \\
\text { a) Intervention } N=187, \text { b) Ctrl } N=54 \\
\text { Mean a) Intervention 64.5yrs (range 21-91) NZ, mean 64.8yrs } \\
\text { (range 20-90) UK, b) Ctrl mean 64.5yrs (range 34-87) } \\
\text { a) Intervention } 57 \% \text { male, b) Ctrl } 56 \% \text { male } \\
\text { Recruited via } 2 \text { regional MMS centres }\end{array}$ & $\begin{array}{l}\text { nRCT - } 2 \text { groups } \\
\text { a) Telephone call - monitoring, information provision } \\
1 \text { call - the evening post surgery } \\
\text { Semi-structured - specific and open Q's } \\
\text { Surgeon-led } \\
\text { b) Standard care }\end{array}$ & $\begin{array}{l}\text { Satisfaction / Perception } \\
\text { Likert scale - NOS } \\
\text { Not validated } \\
\text { Comments / feedback from } \\
\text { patients }\end{array}$ & $\begin{array}{l}5-7 \text { days after phone call } \\
\text { AD: } \\
\text { Intervention } N=187 \text { (\% unclear) } \\
\text { Ctrl } N=54 \text { (\% unclear) }\end{array}$ & Quant (low) \\
\hline $\begin{array}{l}\text { Hagopian \& } \\
\text { Rubenstein } \\
1990 \\
\text { USA }\end{array}$ & $\begin{array}{l}\text { Variety cancer pts receiving RT } \\
\text { a) Intervention } N=27, \text { b) Ctrl } N=28 \\
\text { Mean } 58 \text { yrs (range } 22-84 \text { ) (TSS only) } \\
33 \% \text { male (TSS only) }\end{array}$ & $\begin{array}{l}\text { RCT - } 2 \text { groups } \\
\text { a) Telephone FU during RT - side effect monitoring, information, anticipatory } \\
\text { guidance, coping strategies, address concerns Weekly, continuing 4-6 weeks post RT } \\
\text { Semi-structured, standardised set of topics } \\
\text { Nurse-led }\end{array}$ & $\begin{array}{l}\text { Satisfaction / Helpfulness } \\
\text { Questionnaire - NOS } \\
\text { Not validated }\end{array}$ & $\begin{array}{l}\text { Timing assessment NR } \\
\text { AD: Intervention group only } \\
N=18(55 \%)\end{array}$ & Quant (low) \\
\hline Low & Recruited via hospital RT Department & b) Standard care & & & Qual (low) \\
\hline $\begin{array}{l}\text { Hegel et al, } \\
2011 \\
\text { USA } \\
\text { Medium }\end{array}$ & $\begin{array}{l}\text { Breast cancer pts receiving } \mathrm{CT} \\
\text { a) Intervention } N=14, \text { b) Ctrl } N=15 \\
\text { Mean } 52.6 \mathrm{yrs}-\mathrm{SD} 9.4 \\
0 \% \text { male } \\
\text { Recruited via cancer centre OP clinic }\end{array}$ & $\begin{array}{l}\text { RCT }-2 \text { groups } \\
\text { a) Problem solving-information provision, motivating, goal setting, support \& } \\
\text { problem solving } 6 \text { weekly sessions } \\
\text { Semi structured intervention following work sheet } \\
\text { Occupational Therapist-led } \\
\text { b) Standard care }\end{array}$ & $\begin{array}{l}\text { Acceptability / Satisfaction } \\
\text { Likert scale } 2 \text { q's (topics provided) } \\
\text { Not validated }\end{array}$ & $\begin{array}{l}6 \text { weeks after the end of the } \\
\text { intervention } \\
\text { AD: Intervention } N=9(64 \%) \\
\text { Ctrl } N=15(100 \%)\end{array}$ & Quant (low) \\
\hline $\begin{array}{l}\text { Heidrich et al, } \\
2009 \\
\text { USA } \\
\text { Medium }\end{array}$ & $\begin{array}{l}\text { Breast cancer pts receiving surgery, CT, RT, HT combinations } \\
\text { a) Intervention } N=20, \text { b) Ctrl } N=21 \\
\text { Mean } 72.5 \text { yrs (range } 68-86 \text { ) } \\
0 \% \text { male } \\
\text { Recruited via cancer centre OP clinic + community advertising }\end{array}$ & $\begin{array}{l}\text { Pilot Study 1: RCT - } 2 \text { groups } \\
\text { a) Individualized Representational Intervention to Improve Symptom Management } \\
\text { - support, symptom monitoring, management plan and strategies, information } \\
\text { provision } \\
5 \text { sessions (baseline, 2, 4, } 6 \text { and } 8 \text { weeks later) } \\
\text { (Baseline session face to face) } \\
\text { Protocold driven intervention } \\
\text { Nurse-led } \\
\text { b) Standard care }\end{array}$ & $\begin{array}{l}\text { Acceptability / Satisfaction } \\
8 \text { q's (topics provided) } \\
\text { Not validated }\end{array}$ & $\begin{array}{l}\text { At } 6 \text { and } 10 \text { weeks post intervention } \\
\text { AD: } \\
\text { Intervention } N=20(100 \%) \\
\text { Ctrl } N=21(100 \%)\end{array}$ & Quant (low) \\
\hline
\end{tabular}

\section{European Journal of Cancer Care}


Page 46 of 53

\begin{tabular}{|c|c|c|c|c|c|}
\hline \multirow[t]{2}{*}{ Medium } & & $\begin{array}{l}\text { Protocol driven intervention } \\
\text { Nurse-led } \\
\text { b) Standard care }\end{array}$ & & & \\
\hline & $\begin{array}{l}\text { Breast cancer pts receiving surgery, CT, RT, HT combinations } \\
N=20 \\
\text { Mean } 67.9 \text { yrs (range } 65-73) \\
0 \% \text { male } \\
\text { Recruited via cancer centre OP clinic + community advertising }\end{array}$ & $\begin{array}{l}\text { Pilot Study 3: Single group } \\
\text { Individualized Representational Intervention to Improve Symptom Management - } \\
\text { support, symptom monitoring, management plan and strategies, information } \\
\text { provision } \\
5 \text { sessions (baseline, 2, } 4,6 \text { and } 8 \text { weeks later) } \\
\text { (Baseline session face to face) } \\
\text { Protocol driven intervention } \\
\text { Nurse-led }\end{array}$ & $\begin{array}{l}\text { Acceptability / Satisfaction } \\
8 \text { q's (topics provided) } \\
\text { Not validated }\end{array}$ & $\begin{array}{l}\text { At } 2,4,6,8 \text { and } 16 \text { weeks } \\
\text { AD: } N=20 \\
(100 \%)\end{array}$ & Quant (low) \\
\hline \multirow[t]{2}{*}{$\begin{array}{l}\text { Inman et al, } \\
2011 \\
\text { USA } \\
\text { Medium }\end{array}$} & \multirow{2}{*}{$\begin{array}{l}\text { Prostate cancer pts post-surgery } \\
\text { a) Intervention } N=30 \text {, b) Ctrl } N=30 \\
\text { Mean } 60.2 \text { yrs- } S \mathrm{DD} 6.99 \\
100 \% \text { male } \\
\text { Recruited via academic centre }\end{array}$} & \multirow{2}{*}{$\begin{array}{l}\text { RCT }-2 \text { groups } \\
\text { a) Educational Intervention }- \text { monitoring, education, information provision } \\
1 \text { session, } 3-5 \text { days post discharge } \\
\text { Intervention algorithm for educational reinforcement } \\
\text { Nurse-led } \\
\text { b) Standard care }\end{array}$} & \multirow{2}{*}{$\begin{array}{l}\text { Satisfaction / Helpfulness } \\
1 \text { closed } q \text { (provided) } \\
\text { Not validated } \\
\text { Comments from patients during } \\
\text { calls }\end{array}$} & \multirow[t]{2}{*}{$\begin{array}{l}30 \text { days after discharge } \\
\mathrm{AD} \text { : } \\
\text { Intervention group only } \\
N=30(100 \%)\end{array}$} & Quant (low) \\
\hline & & & & & Qual (low) \\
\hline $\begin{array}{l}\text { Jefford et al, } \\
2011 \\
\text { Australia } \\
\text { Medium }\end{array}$ & $\begin{array}{l}\text { Colorectal cancer pts receiving surgery, CT, RT, combinations } \\
N=10 \\
\text { Mean } 55 \text { yrs (range } 35-71 \text { ) (TSS only) } \\
50 \% \text { male (TSS only) } \\
\text { Recruited via cancer centre }\end{array}$ & $\begin{array}{l}\text { Quasi-experimental - Single group } \\
\text { Post treatment support package - education, information provision, monitoring, } \\
\text { support, coaching, health promotion } \\
4 \text { sessions ( } 1 \text { st at end of treatment, then } 1,3 \text { and } 7 \text { weeks later) } \\
\text { (one session face-to-face - package included DVD and written information) } \\
\text { Semi-structured intervention - manual for } 1 \text { st session } \\
\text { Nurse }\end{array}$ & $\begin{array}{l}\text { Satisfaction } \\
\text { Interview - NOS }\end{array}$ & $\begin{array}{l}\text { After } 3^{\text {rd }} \text { pone call (NOS) } \\
\text { AD: } N=8(80 \%)\end{array}$ & Qual (low) \\
\hline $\begin{array}{l}\text { Jensen et al, } \\
2011 \\
\text { Denmark } \\
\text { Medium }\end{array}$ & $\begin{array}{l}\text { Prostate cancer pts following prostatectomy } \\
\text { a) Intervention } N=46 \text {, b) Ctrl } N=49 \\
\text { Mean a) Intervention 64.1yrs (95\% } 62 \text { C2.5-65.8), b) Ctrl } 62 . \\
\text { 5yrs (95\%CI } 60.9-64.2 \text { ) } \\
100 \% \text { male } \\
\text { Recruited via urology centre }\end{array}$ & $\begin{array}{l}\text { RCT }-2 \text { groups } \\
\text { a) Telephone FU - NOS } \\
1 \text { session } 3 \text { days after discharge } \\
\text { Semi structured intervention - manual for interview } \\
\text { Nurse-led } \\
\text { b) Standard care }\end{array}$ & $\begin{array}{l}\text { Satisfaction } \\
\text { Likert questionnaire (topic } \\
\text { provided) - NOS } \\
\text { Not validated }\end{array}$ & $\begin{array}{l}2 \text { weeks post-op } \\
\mathrm{AD} \text { : } \\
\text { Intervention only } N=46(100 \%)\end{array}$ & Quant (low) \\
\hline \multirow[t]{2}{*}{$\begin{array}{l}\text { Kelly et al, } 1999 \\
\text { Canada } \\
\text { Low }\end{array}$} & \multirow[t]{2}{*}{$\begin{array}{l}\text { Ovarian cancer pts receiving CT } \\
N=50 \\
\text { Age NR } \\
0 \% \text { male } \\
\text { Recruited via OP CT clinic }\end{array}$} & \multirow[t]{2}{*}{$\begin{array}{l}\text { Non-experimental - Single group } \\
\text { Telephone FU - symptom monitoring, information provision, support } \\
\text { Calls 5-7 days post CT and once every 3-4 weeks during CT - NOS } \\
\text { Semi-structured intervention - assessment tool to follow } \\
\text { Nurse-led }\end{array}$} & \multirow{2}{*}{$\begin{array}{l}\text { Benefit / Acceptability / } \\
\text { Helpfulness } \\
4 \text { closed q's (topics provided) } \\
\text { Not validated } \\
2 \text { open q's (topics provided) } \\
\text { Not validated }\end{array}$} & \multirow[t]{2}{*}{$\begin{array}{l}\text { Evaluation time point NR } \\
\mathrm{AD}: N=31(62 \%)\end{array}$} & Quant (low) \\
\hline & & & & & Qual (low) \\
\hline \multirow[t]{2}{*}{$\begin{array}{l}\text { Kilbourn et al, } \\
2013 \\
\text { USA } \\
\text { Low }\end{array}$} & \multirow{2}{*}{$\begin{array}{l}\text { Head \& neck cancer pts receiving RT } \\
N=16 \\
\text { Mean } 59.66 y \mathrm{yr} \text { - SD9.78 (TSS only) } \\
76.2 \% \text { male (TSS only) } \\
\text { Recruited via radiation oncology clinic (convenience sample) }\end{array}$} & \multirow{2}{*}{$\begin{array}{l}\text { Quasi-experimental - Single group } \\
\text { Easing + Alleviating Symptoms during treatment - stress management, coping skills } \\
\text { training, psycho-education to increase understanding of treatment related side effects } \\
2 \text {-10 sessions } 50 \% \text { received } 4-6 \text { sessions) } \\
\text { Structure NR } \\
\text { Psychologist led }\end{array}$} & $\begin{array}{l}\text { Satisfaction } \\
\text { Likert scale } 2 \text { q's (topics provided) } \\
\text { Not validated }\end{array}$ & \multirow{2}{*}{$\begin{array}{l}\text { Evaluation timepoint } \mathrm{NR} \\
\mathrm{AD} \text { : } \\
\text { Process evaluation } N=11(69 \%) \\
\text { Qualitative interviews } \\
N=8(50 \%)\end{array}$} & Quant (low) \\
\hline & & & Exit interviews - NOS & & Oual (low) \\
\hline $\begin{array}{l}\text { Kim et al, } 2011 \\
\text { South Korea } \\
\text { Medium }\end{array}$ & $\begin{array}{l}\text { Breast cancer pts receiving surgery, RT, CT or HT } \\
\text { a) Intervention } N=23 \text {, b) Ctrl } N=22 \text { ) } \\
\text { Mean a) Intervention } 44.6 y r s(\text { tange } 26-69) \text {, b) Ctrl NR (TSS } \\
\text { only) } \\
0 \% \text { male } \\
\text { Recruited via cancer centre }\end{array}$ & $\begin{array}{l}\text { RCT }-2 \text { groups } \\
\text { a) Individualised diet and exercise counselling - monitoring, motivation, support, } \\
\text { information provision } \\
12 \text { weekly sessions } \\
\text { Semi-structured - use of telephone counselling protocol } \\
\text { Nurse-led } \\
\text { b) Standard care }\end{array}$ & $\begin{array}{l}\text { Feasibility / Helpfulness } \\
\text { Likert scale (topics provided) } \\
\text { Not validated }\end{array}$ & $\begin{array}{l}\text { Baseline and } 12 \text { weeks after } \\
\text { intervention } \\
\text { AD: Intervention group only } N=14 \\
(61 \%)\end{array}$ & Quant (low) \\
\hline
\end{tabular}

\section{European Journal of Cancer Care}




\begin{tabular}{|c|c|c|c|c|c|}
\hline $\begin{array}{l}\text { Kimman et al, } \\
2010 \\
\text { Netherlands } \\
\text { High }\end{array}$ & $\begin{array}{l}\text { Breast cancer pts receiving surgery, RT, CT or HT } \\
\text { Study compared hospital FU groups }(\text { Ctrl a) }+ \text { c)) vs telephone } \\
\text { FU groups (Intervention b) }+ \text { d)) } \\
\text { b+d) Intervention } N=120, a+c) \text { Ctrl } N=149 \\
\text { Mean b+d) Intervention } 55 y \text { yrs }- \text { SD } 9,(\text { TSS only) a }+ \text { c) Ctrl } 56 \\
\text { yrs }- \text { SD } 10.7 \\
0 \% \text { male } \\
\text { Recruited via } 7 \text { hospitals + } 2 \text { RT clinics }\end{array}$ & $\begin{array}{l}\text { RCT - } 4 \text { groups } \\
\text { a) Standard hospital FU - } 4 \text { sessions, 3monthly } \\
\text { b) Telephone FU- } 4 \text { sessions, } 3 \text { monthly } \\
\text { c) Hospital FU + Educational Group Program } 2 \text { EGP sessions within } 3 \text { months } \\
\text { after treatment } \\
\text { d) Telephone FU + Educational Group Program } \\
4 \text { sessions, } 3 \text { monthly and } 2 \text { EGP sessions within } 3 \text { months after treatment } \\
\text { (Telephone FU - symptom monitoring, treatment side effect management, drug } \\
\text { compliance) } \\
\text { (Educational Group Program - education, information coping strategies, group } \\
\text { discussion) } \\
\text { (Groups c) + d) received } 2 \text { group sessions) } \\
\text { Structured educational group sessions } \\
\text { Nurse delivered telephone FU } \\
\text { Nurse + psychologist delivered EGP }\end{array}$ & $\begin{array}{l}\text { Satisfaction } \\
\text { PSQIII } \\
\text { Validated }\end{array}$ & $\begin{array}{l}\text { Baseline, } 3,6 \text { and } 12 \text { mths post } \\
\text { treatment } \\
\text { AD: } \\
\text { Intervention } N=120(100 \%) \\
\text { Ctrl } N=149(100 \%)\end{array}$ & Quant (low) \\
\hline $\begin{array}{l}\text { Leahy et al } 2013 \\
\text { Australia } \\
\text { Medium }\end{array}$ & $\begin{array}{l}\text { Prostate cancer pts receiving HT, RT, brachytherapy, } \\
\text { prostatectomy or WW } \\
\text { a) Intervention } N=86 \text {, b) Ctrl } N=83 \\
\text { Mean a) Intervention } 68.4 \text { yrs (range } 49-80 \text { ), b) Ctrl } 70.2 \text { yrs } \\
\text { (range 55-82) } \\
100 \% \text { male } \\
\text { Recruited via cancer centre OP clinics }\end{array}$ & $\begin{array}{l}\text { nRCT - } 2 \text { groups } \\
\text { a) Telephone FU - general and symptom monitoring, PSA level review, information } \\
\text { provision } \\
\text { Once every } 6 \text { months - NOS } \\
\text { Structured intervention following evidence based algorithms } \\
\text { Nurse-led } \\
\text { b) Standard care }\end{array}$ & $\begin{array}{l}\text { Satisfaction } \\
\text { Adapted Satisfaction with } \\
\text { Consultation Scale } \\
\text { Not re-validated }\end{array}$ & $\begin{array}{l}1 \text { week after intervention } \\
\mathrm{AD} \text { : } \\
\text { Intervention } N=86 \\
(100 \%) \\
\text { Ctrl } N=83(100 \%)\end{array}$ & Quant (low) \\
\hline $\begin{array}{l}\text { Livingston et al } \\
2010 \text { A } \\
\text { Australia } \\
\text { Medium }\end{array}$ & $\begin{array}{l}\text { Colorectal cancer pts post CT } \\
N=59 \\
\text { Range } 30-79 \mathrm{yrs} \\
63 \% \text { male } \\
\text { Recruited via } 6 \text { public + private health services }\end{array}$ & $\begin{array}{l}\text { Quasi-experimental - Single group } \\
\text { Screening for depression post CT - DIT completion, information provision, } \\
\text { support, referral to psycho-oncologist } \\
2 \text { sessions ( } 1 \text { st } 7 \text {-10 days post recruitment, } 2^{\text {nd }} 4 \text { weeks later) } \\
\text { Intervention based on clinical practice guidelines } \\
\text { Nurse-led }\end{array}$ & $\begin{array}{l}\text { Experience / Perception / } \\
\text { Satisfaction } \\
\text { Likert scale questionnaire (topics } \\
\text { provided) } \\
\text { Not validated }\end{array}$ & $\begin{array}{l}1 \text { mth after last call } \\
\mathrm{AD}: \\
N=45(100 \%)\end{array}$ & Quant (low) \\
\hline & & & $\begin{array}{l}\text { Telephone interview with open } \\
\text { questions - NOS }\end{array}$ & NR & Qual (low) \\
\hline $\begin{array}{l}\text { Marcus et al, } \\
1993 \\
\text { USA } \\
\text { Low }\end{array}$ & $\begin{array}{l}\text { Breast cancer pts post adjuvant treatment } \\
N=30 \\
\text { Mean } 49.9 \text { yrs (range } 40-70 \text { ) } \\
0 \% \text { male } \\
\text { Recruited via } 4 \text { Hospitals }+1 \text { cancer clinic }\end{array}$ & $\begin{array}{l}\text { Quasi-experimental - Single group } \\
\text { Telephone counselling - interviews assessing physical and psychosocial concerns - } \\
\text { NOS } \\
\text { Timing NR } \\
\text { Structure NR } \\
\text { Counsellor-led }\end{array}$ & $\begin{array}{l}\text { Feasibility } \\
1 \text { evaluation indicator (provided) } \\
\text { Not validated }\end{array}$ & $\begin{array}{l}\text { Evaluation timing NR } \\
\mathrm{AD}: N=30(100 \%)\end{array}$ & Quant (low) \\
\hline $\begin{array}{l}\text { Marcus et al, } \\
2010 \\
\text { USA } \\
\text { Medium }\end{array}$ & $\begin{array}{l}\text { Breast cancer pts post treatment } \\
\text { a) Intervention } N=152 \text {, b) Ctrl } N=152 \\
\text { 'About half the sample was } 50 \text { yrs of age or less' } \\
\text { a) Intervention (range }<40-70+\text { b) Ctrl (range }<40-70+\text { ) } \\
0 \% \text { male } \\
\text { Recruited in } 21 \text { hospitals \& medical centres nationwide }\end{array}$ & $\begin{array}{l}\text { RCT }-2 \text { groups } \\
\text { a) Booklet provided listing psychosocial + rehabilitation services in their community } \\
+ \text { telephone counselling over } 12 \text { months }-6 \text { modules: living with uncertainty, } \\
\text { physical change, self-change, sexuality, relationships, economic change } \\
16 \text { sessions }-9 \text { sessions at bi-wkly intervals, } 7 \text { sessions monthly } \\
\text { Structured }- \text { thematic modules, guides, worksheets (prioritised by participant) } \\
\text { Psycho-oncology counsellors } \\
\text { b) Booklet provided listing psychosocial + rehabilitation services in their community }\end{array}$ & $\begin{array}{l}\text { Helpfulness } \\
\text { Questionnaire on component of } \\
\text { intervention which was most } \\
\text { helpful (provided) } \\
\text { Not validated }\end{array}$ & $\begin{array}{l}\text { End of intervention } \\
\text { AD: Intervention group only } N=129 \\
(85 \%)\end{array}$ & Quant (low) \\
\hline $\begin{array}{l}\text { Mordenti et al, } \\
2013 \\
\text { Italy } \\
\text { Low }\end{array}$ & $\begin{array}{l}\text { Patients receiving CT - NOS } \\
N=170 \\
\text { Age NR } \\
\text { Gender NR } \\
\text { Recruitment - consecutive patients invited - NOS }\end{array}$ & $\begin{array}{l}\text { Quasi-experimental - Single group } \\
\text { Telephone support post CT - monitoring, education and support } \\
\text { One call the 1st day after } 1 \text { st cycle of CT } \\
\text { Structured (3q's) } \\
\text { Nurse-led }\end{array}$ & $\begin{array}{l}\text { Usefulness } \\
\text { Survey (topics provided) } \\
\text { Not validated }\end{array}$ & $\begin{array}{l}\text { At the following visit } \\
\text { AD: } N=170(100 \%)\end{array}$ & Quant (low) \\
\hline
\end{tabular}

\section{European Journal of Cancer Care}


Page 48 of 53

\begin{tabular}{|c|c|c|c|c|c|}
\hline & Recruited via RT department & $\begin{array}{l}\text { Radiographer, nurse or doctor led } \\
\text { b) Standard care }\end{array}$ & & & \\
\hline $\begin{array}{l}\text { Reese et al, } \\
2012 \\
\text { USA } \\
\text { Medium }\end{array}$ & $\begin{array}{l}\text { Colorectal cancer pts post-surgery, RT / CT combinations (and } \\
\text { partners) } \\
N=9 \\
\text { Mean } 61.6 y r s-S D 14.5 \\
56 \% \text { male } \\
\text { Recruited via cancer centre registry, medical record screening, } \\
\text { GI cancer clinic, self- referral }\end{array}$ & $\begin{array}{l}\text { Quasi-experimental - Single group } \\
\text { Intimacy enhancement program - education, behavioural skills for coping, } \\
\text { improving sexual intimacy, intimacy building activities } \\
\text { Weekly sessions over mean } 5.1 \mathrm{wks} \text { (SD1.1) } \\
\text { Manual provided } \\
\text { Agent NR }\end{array}$ & $\begin{array}{l}\text { Acceptability / Ease of } \\
\text { participation / Helpfulness } \\
\text { Likert scale 4q's (topics provided) } \\
\text { Not validated }\end{array}$ & $\begin{array}{l}\text { Evaluation timing } \mathrm{NR} \\
\mathrm{AD}: \\
N=9 \text { (and } 9 \text { partners) }(100 \%)\end{array}$ & Quant (low) \\
\hline $\begin{array}{l}\text { Reese et al, } \\
2014 \\
\text { USA } \\
\text { Medium }\end{array}$ & $\begin{array}{l}\text { Colorectal cancer pts post-surgery / on treatment (and } \\
\text { partners) } \\
\text { a) Intervention } N=10 \text {, b) Ctrl } N=8 \\
\text { Mean a) Intervention } 48.7 \mathrm{yrs}-\mathrm{SD} 11, \text { b) Ctrl } 57.4 \mathrm{yrs}-\mathrm{SD} 8.4 \\
\text { a) Intervention } 60 \% \text { male, b) Ctrl } 60 \% \text { male } \\
\text { Recruited via cancer centre registry, medical record screening, } \\
\text { GI cancer clinic, self- referral }\end{array}$ & $\begin{array}{l}\text { RCT }-2 \text { groups } \\
\text { a) Intimacy enhancement program - education, behavioural skills for coping, } \\
\text { improving sexual intimacy, intimacy building activities } \\
\text { Weekly sessions over mean } 4.8 \text { wks (SD2.5) } \\
\text { Manual provided } \\
\text { Psychologist-led } \\
\text { b) Standard care }\end{array}$ & $\begin{array}{l}\text { Acceptability / Ease of } \\
\text { participation / Helpfulness } \\
\text { Likert scale 3q's (topics provided) } \\
\text { Not validated }\end{array}$ & $\begin{array}{l}\text { Evaluation timing NR } \\
\text { AD: Intervention group only } N=10 \\
(\text { and } 10 \text { partners }) \\
(100 \%)\end{array}$ & Quant (low) \\
\hline \multirow{2}{*}{$\begin{array}{l}\text { Salonen et al, } \\
2009 \\
\text { Finland } \\
\text { Medium }\end{array}$} & \multirow{2}{*}{$\begin{array}{l}\text { Breast cancer pts post-surgery } \\
\text { a) Intervention } N=120 \text {, b) Ctrl } N=108, \\
\text { Mean a) Intervention } 57 \text { yrs (range } 31-75) \text {, b) Ctrl } 56 \text { yrs (range } \\
24-75 \text { ) } \\
0 \% \text { male } \\
\text { Recruited via departments of Oncology + Surgery }\end{array}$} & \multirow{2}{*}{$\begin{array}{l}\text { nRCT }-2 \text { groups } \\
\text { a) Social support }- \text { education, information provision, instructions for exercise, } \\
\text { support, health education } \\
1 \text { session } 1 \text { week post surgery } \\
\text { Semi-structured interview manual } \\
\text { Physiotherapist-led } \\
\text { b) Standard care }\end{array}$} & \multirow{2}{*}{$\begin{array}{l}\text { Perception } \\
\text { Revised likert scale [80] } \\
\text { Validated } \\
1 \text { open ended q (topic provided) }\end{array}$} & \multirow[t]{2}{*}{$\begin{array}{l}\text { Within } 2 \text { weeks after discharge } \\
\text { AD: Intervention group only } \\
N=\text { unclear (unclear } \%)\end{array}$} & Quant (low) \\
\hline & & & & & Qual (low) \\
\hline $\begin{array}{l}\text { Sandgren et al, } \\
2000 \\
\text { USA } \\
\text { Medium }\end{array}$ & $\begin{array}{l}\text { Breast cancer pts receiving surgery, RT, CT or HT } \\
\text { combinations } \\
\text { a) Intervention } N=24, \text { b) Ctrl } N=29 \\
\text { Mean a) Intervention } 51.23 \text { yrs - SD } 12.5 \text {, b) Ctrl age NR (TSS } \\
\text { only) } \\
0 \% \text { male } \\
\text { Recruited via hospital - NOS }\end{array}$ & $\begin{array}{l}\text { RCT }-2 \text { groups } \\
\text { a) Cognitive Behavioral Therapy }- \text { support, teaching coping skills, managing anxiety } \\
\& \text { stress, problem solving } \\
10 \text { sessions } \\
\text { Structurekly for } 4 \text { weeks then bi-weekly) } \\
\text { Clinical Psychology Masters Candidate-led } \\
\text { b) Standard care }\end{array}$ & $\begin{array}{l}\text { Value } \\
\text { Likert scale 4q's (provided) } \\
\text { Not validated }\end{array}$ & $\begin{array}{l}4 \text { and } 10 \text { mth FU intervals } \\
\text { AD: Intervention group only } N=24 \\
(100 \%)\end{array}$ & Quant (low) \\
\hline $\begin{array}{l}\text { Sardell et al, } \\
2000 \\
\text { UK } \\
\text { Medium }\end{array}$ & $\begin{array}{l}\text { Neurological cancer pts receiving surgery or RT } \\
N=45 \\
\text { Median 50yrs (range 23-69) (TSS only) } \\
67 \% \text { male (TSS only) } \\
\text { Recruited via hospital - NOS }\end{array}$ & $\begin{array}{l}\text { nRCT - } 2 \text { groups } \\
\text { a) Telephone FU - general \& symptom monitoring, medication issues, support, } \\
\text { information, ADL assessment } \\
3 \text { sessions (monthly over } 3 \text { months) } \\
\text { Semi-structured questionnaire } \\
\text { Nurse-led } \\
\text { b) Standard care }\end{array}$ & $\begin{array}{l}\text { Satisfaction } \\
\text { Satisfaction questionnaire (topics } \\
\text { provided) } \\
\text { Not validated }\end{array}$ & $\begin{array}{l}\text { Unclear - pts still receiving telephone } \\
\text { FU } \\
\text { AD: Intervention group only } N=22 \\
(49 \%)\end{array}$ & Quant (low) \\
\hline $\begin{array}{l}\text { Smithies et al, } \\
2009 \\
\text { Canada } \\
\text { Medium }\end{array}$ & $\begin{array}{l}\text { Breast cancer pts receiving CT } \\
N=20 \\
\text { Mean } 54 \text { yrs }-\mathrm{SD} 8.2 \\
0 \% \text { male } \\
\text { Recruited via hospital cancer centre }\end{array}$ & $\begin{array}{l}\text { Quasi-experimental - Single group } \\
\text { Telephone support post } 1 \text { st chemotherapy - symptom monitoring, provision of } \\
\text { information, support } \\
1 \text { session (average } 3 \text { days post CT, range 1-5) } \\
\text { Checklist questionnaire } \\
\text { Member of research team, nurse or doctor }\end{array}$ & $\begin{array}{l}\text { Value / Utility } \\
\text { Likert scale 1q (topic provided) } \\
\text { Not validated } \\
\text { Method NR }\end{array}$ & $\begin{array}{l}\text { Post consultation - NOS } \\
\text { AD: } N=20(100 \%)\end{array}$ & $\frac{\text { Quant (low) }}{\text { Qual (low) }}$ \\
\hline \multirow{2}{*}{$\begin{array}{l}\text { Steginga et al, } \\
2007 \\
\text { Australia } \\
\text { Medium }\end{array}$} & \multirow{2}{*}{$\begin{array}{l}\text { Prostate cancer pts receiving RT, brachytherapy, prostatectomy } \\
\text { combinations or WW } \\
N=20 \\
\text { Mean } 63 \mathrm{yrs}-\mathrm{SD} 6.7 \\
100 \% \text { male }\end{array}$} & \multirow{2}{*}{$\begin{array}{l}\text { Quasi-experimental - Single group } \\
\text { Telephone counselling - decision support, stress management, preparation for } \\
\text { treatment, adjustment to cancer, problem solving, coping strategies } \\
4 \text { sessions ( } 2 \text { pre-treatment and at } 4 \text { and } 7 \text { weeks post) } \\
\text { Nurse-led } \\
\text { Structured counselling protocols }\end{array}$} & \multirow{2}{*}{$\begin{array}{l}\text { Acceptability } \\
\text { Likert scale 1q (topic provided) } \\
\text { Not validated } \\
\text { Verbatim responses (topics } \\
\text { provided) }\end{array}$} & \multirow[t]{2}{*}{$\begin{array}{l}2 \text { mths post treatment } \\
\mathrm{AD}: N=20(100 \%)\end{array}$} & Quant (low) \\
\hline & & & & & Qual (low) \\
\hline $\begin{array}{l}\text { Wilmoth et al, } \\
2006\end{array}$ & $\begin{array}{l}\text { Breast cancer pts receiving surgery, CT, RT, HT or no } \\
\text { treatment }\end{array}$ & $\begin{array}{l}\text { Nested - subjects from } 2 \text { groups } \\
\text { a) Educational materials and telephone social support - information provision }\end{array}$ & Comments about the project & End of study (13mths) & \\
\hline
\end{tabular}

\section{European Journal of Cancer Care}




\section{Page 49 of 53}

\begin{tabular}{|c|c|c|c|c|c|}
\hline $\begin{array}{l}\text { USA } \\
\text { High }\end{array}$ & $\begin{array}{l}\text { a) Intervention } N=35 \text {, b) Ctrl } N=42 \\
\text { Mean a) Intervention } 57 \mathrm{yrs} \text {, b) Ctrl } 59 \mathrm{yrs} \\
0 \% \text { male } \\
\text { Sample of patients participating in an RCT with a telephone } \\
\text { intervention vs standard care } \\
\text { Recruited via hospital + community - NOS }\end{array}$ & $\begin{array}{l}\text { Unclear number of telephone sessions (initially weekly, then bi-weekly, then monthly } \\
\text { up to } 13 \text { months post surgery) } \\
\text { Semi-structured intervention with manual supporting educational materials } \\
\text { Nurse-led } \\
\text { b) Standard care + educational materials }\end{array}$ & $\begin{array}{l}\text { Interview with schedule (topics } \\
\text { provided) }\end{array}$ & $\begin{array}{l}\text { AD: Intervention group only } \\
N=35(100 \%)\end{array}$ & Qual (high) \\
\hline \multirow{2}{*}{$\begin{array}{l}\text { Young et al, } \\
2010 \\
\text { Australia } \\
\text { Medium }\end{array}$} & $\begin{array}{l}\text { Colorectal cancer pts post-surgery / receiving adjuvant therapy } \\
\text { a) Intervention } N=20 \text {, b) } \mathrm{Ctrl} N=21 \\
\text { Mean a) Intervention } 66.9 \mathrm{yrs}, \text { b) Ctrl } 14.5 \mathrm{yrs} \text { (TSS only) } \\
\text { a) Intervention } 60 \% \text { male, b) } \mathrm{Ctrl} 50 \% \text { male (TSS only) }\end{array}$ & \multirow{2}{*}{$\begin{array}{l}\text { nRCT }-2 \text { groups } \\
\text { a) Telephone support }- \text { general and side effect monitoring, information provision, } \\
\text { emotional support, advice } \\
5 \text { sessions (day } 3 \text { and } 10,1 \mathrm{mth}, 3 \mathrm{mth} \text { th and } 6 \mathrm{~m} \text { ths post discharge) } \\
\text { Standardised checklist screening for patients needs } \\
\text { Nurse-led } \\
\text { b) Standard care }\end{array}$} & \multirow{2}{*}{$\begin{array}{l}\text { Views of content and timing } \\
\text { Questionnaire - NOS } \\
\text { Not validated }\end{array}$} & \multirow[t]{2}{*}{$\begin{array}{l}\text { 6mths after hospital discharge } \\
\text { AD: Intervention group only } N=13 \\
(65 \%)\end{array}$} & Quant (low) \\
\hline & Recruited via hospital & & & & Qual (low) \\
\hline \multirow[t]{2}{*}{$\begin{array}{l}\text { Young et al, } \\
2013 \\
\text { Australia } \\
\text { Low }\end{array}$} & \multirow[t]{2}{*}{$\begin{array}{l}\text { Colorectal cancer pts post--surgery } \\
\text { a) Intervention } N=387 \text {, b) Ctrl } N=369 \\
\text { Mean a) Intervention } 68.6 y r s \\
\text { a) In } 12.2, \text { b) Ctrl } 67.0 y r s-S D 12.1 \\
\text { a) Intervention } 56.8 \% \text { male, b) Ctrl } 54.2 \% \text { male } \\
\text { Recruitment NR }\end{array}$} & \multirow{2}{*}{$\begin{array}{l}\text { RCT - } 2 \text { groups } \\
\text { a) Telephone support - general and side effect monitoring, information provision, } \\
\text { emotional support, advice } \\
5 \text { sessions (day } 3 \text { and } 10,1 \mathrm{mth}, 3 \mathrm{mths} \text { and } 6 \mathrm{~m} \text { ths post discharge) } \\
\text { tandardised checklist screening for patients needs } \\
\text { Nurse-led } \\
\text { b) Standard care }\end{array}$} & \multirow{2}{*}{$\begin{array}{l}\text { Views of intervention } \\
\text { Likert scale } 13 \text { statements } \\
\text { (provided) } \\
\text { Not validated } \\
\text { Semi-structured interviews - NOS }\end{array}$} & \multirow[t]{2}{*}{$\begin{array}{l}\text { Questionnaire at } 6 \mathrm{mths} \\
\text { Every } 3 \text { mths semi-structured } \\
\text { interviews } \\
\text { AD: Intervention group only } \\
\text { Quantitative } N=350(90 \%) \\
\text { Qualitative } \mathrm{n}=29(7 \%)\end{array}$} & Quant (low) \\
\hline & & & & & Qual (low) \\
\hline $\begin{array}{l}\text { Zhang et al, } \\
2013 \\
\text { China } \\
\text { High }\end{array}$ & $\begin{array}{l}\text { Rectal cancer pts post-surgery } \\
\text { a) Intervention } N=59 \text {, b) Ctrl } N=60 \\
\text { Mean a) Intervention } 52.9 \text { yrs }-\mathrm{SD} 13.3, \text { b) Ctrl } 55.3 \mathrm{yrs}- \\
\text { SD } 13.7 \\
\text { a) Intervention } 59.6 \% \text { male, b) Ctrl } 70.6 \% \text { male } \\
\text { Recruited via regional hospitals }\end{array}$ & 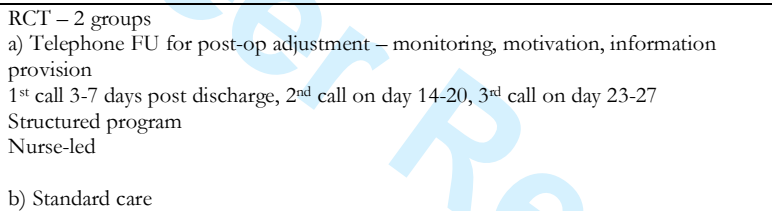 & $\begin{array}{l}\text { Likert scale } 1 \mathrm{q} \text { (topic provided) } \\
\text { Not validated }\end{array}$ & $\begin{array}{l}\text { At } 1 \text { and } 3 \text { months after discharge } \\
\text { AD: Intervention group only } N=52 \\
(88 \%)\end{array}$ & Quant (low) \\
\hline $\begin{array}{l}\text { Zheng et al, } \\
2013 \\
\text { China } \\
\text { High }\end{array}$ & $\begin{array}{l}\text { Colorectal cancer pts post-surgery } \\
\text { Random sample of patients receiving telephone intervention } \\
(N=59-\text { main study) }[31] \\
\text { Recruitment NR }\end{array}$ & $\begin{array}{l}\text { Nested - Single group } \\
\text { Telephone FU for post-op adjustment - monitoring, motivation, information } \\
\text { provision } \\
1^{\text {st }} \text { call } 3-7 \text { days post discharge, } 2^{\text {nd }} \text { call on day } 14-20,3^{\text {rd }} \text { call on day } 23-27 \\
\text { tructured program } \\
\text { Nurse }\end{array}$ & $\begin{array}{l}\text { Explore perceptions of telephone } \\
\text { FU } \\
\text { Semi-structured interviews (topics } \\
\text { provided) }\end{array}$ & $\begin{array}{l}\text { Evaluation timing } \mathrm{NR} \\
\mathrm{AD}: \mathrm{N}=11 \text { (NR) }\end{array}$ & Qual (high) \\
\hline
\end{tabular}

Micrographic Surgery, NOS - Not Otherwise Specified, NR - Not Reported, nRCT - non-Randomised Controlled Trial, OP - Outpatient, PSQ III - Ware's Putient Satisfaction - Huestionnaire III, RCT - Randomised Controlled Trial, RT - Radiotherapy, SD Standard Deviation, THE - Telephone health education, TIC - Telephone interpersonal counselling, TSS - Total Sample Size, VIC - Videophone interpersonal counselling, WW - Watch \& Wait 
Table 7: Acceptability / Satisfaction Data Quality

\section{Qualitative Data}

\begin{tabular}{|c|c|c|c|c|}
\hline $\begin{array}{l}\text { First Author / } \\
\text { Date }\end{array}$ & 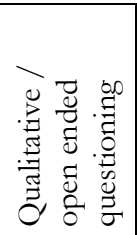 & 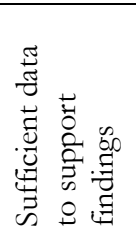 & 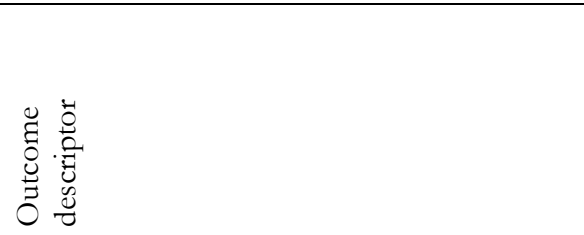 & 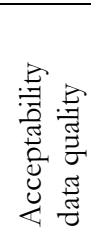 \\
\hline Alter et al, 1996 & $\mathrm{Y}$ & $\mathrm{N}$ & Discussion of intervention - NOS & Low \\
\hline $\begin{array}{l}\text { Archer et al, } \\
2014\end{array}$ & $\mathrm{Y}$ & $\mathrm{Y}$ & Semi structured interviews -NOS & High \\
\hline $\begin{array}{l}\text { Badger et al, } \\
2013\end{array}$ & $\mathrm{~N}$ & $\mathrm{~N}$ & Open ended q's (topic provided) & Low \\
\hline $\begin{array}{l}\text { Beaver et al, } \\
2010\end{array}$ & $\mathrm{Y}$ & $\mathrm{Y}$ & Semi structured interviews (topics provided) & High \\
\hline $\begin{array}{l}\text { Booker et al, } \\
2004\end{array}$ & Y & $\mathrm{N}$ & Comments & Low \\
\hline $\begin{array}{l}\text { Campbell et al, } \\
2007\end{array}$ & Y & $\mathrm{Y}$ & $\begin{array}{l}\text { 1q - what was it like to undergo CST by } \\
\text { telephone? }\end{array}$ & High \\
\hline $\begin{array}{l}\text { Cimprich et al, } \\
2005\end{array}$ & Y & $\mathrm{U}$ & 2 open ended q's (topics provided) & Low \\
\hline Cox et al, 2008 & $\mathrm{Y}$ & $\mathrm{U}$ & $\begin{array}{l}\text { Open section on general views of care } \\
\text { experienced - NOS }\end{array}$ & Low \\
\hline Dixon, 2010 & $\mathrm{U}$ & $\mathrm{U}$ & Comments during telephone calls & Low \\
\hline $\begin{array}{l}\text { Donnelly et al, } \\
2013\end{array}$ & $\mathrm{Y}$ & $\mathrm{Y}$ & $\begin{array}{l}\text { Focus groups with open ended q's (topics } \\
\text { provided) }\end{array}$ & High \\
\hline Hafiji et al, 2012 & $\mathrm{Y}$ & $\mathrm{U}$ & Comments / feedback & Low \\
\hline $\begin{array}{l}\text { Hagopian \& } \\
\text { Rubenstein, } \\
1990\end{array}$ & $\mathrm{U}$ & $\mathrm{U}$ & Comments & Low \\
\hline $\begin{array}{l}\text { Inman et al, } \\
2011\end{array}$ & $\mathrm{Y}$ & $\mathrm{U}$ & Comments from patients during calls & Low \\
\hline $\begin{array}{l}\text { Jefford et al, } \\
2011\end{array}$ & $\mathrm{Y}$ & $\mathrm{Y}$ & Interview - NOS & High \\
\hline Kelly, 1999 & $\mathrm{Y}$ & $\mathrm{U}$ & 2 open q’s (improvements / positive effects) & Low \\
\hline $\begin{array}{l}\text { Kilbourn et al, } \\
2013\end{array}$ & $\mathrm{U}$ & $\mathrm{U}$ & Exit interviews - NOS & Low \\
\hline $\begin{array}{l}\text { Livingston et al, } \\
2010\end{array}$ & $\mathrm{Y}$ & $\mathrm{N}$ & $\begin{array}{l}\text { Telephone interview with open questions - } \\
\text { NOS }\end{array}$ & Low \\
\hline $\begin{array}{l}\text { Salonen et al, } \\
2009\end{array}$ & $\mathrm{Y}$ & $\mathrm{N}$ & $\begin{array}{l}1 \text { open ended q (most appropriate timing for } \\
\text { call) }\end{array}$ & Low \\
\hline $\begin{array}{l}\text { Smithies et al, } \\
2009\end{array}$ & $\mathrm{U}$ & $\mathrm{U}$ & Method NR & Low \\
\hline $\begin{array}{l}\text { Steginga et al, } \\
2007\end{array}$ & $\mathrm{Y}$ & $\mathrm{U}$ & Verbatim responses (topics provided) & Low \\
\hline $\begin{array}{l}\text { Wilmoth et al, } \\
2006\end{array}$ & $\mathrm{Y}$ & $\mathrm{Y}$ & Interviews with schedule (topics provided) & High \\
\hline $\begin{array}{l}\text { Young et al, } \\
2013\end{array}$ & $\mathrm{Y}$ & $\mathrm{U}$ & Semi structured interviews & Low \\
\hline $\begin{array}{l}\text { Zheng et al, } \\
2013\end{array}$ & $\mathrm{Y}$ & $\mathrm{Y}$ & Semi structured interviews (topics provided) & High \\
\hline
\end{tabular}

CST - coping skills training, N - No, NOS - Not Otherwise Specified, NR - Not reported, U - Unclear, Y -

Yes 


\section{Quantitative Data}

\begin{tabular}{|c|c|c|c|c|}
\hline $\begin{array}{l}\text { Author / } \\
\text { Date }\end{array}$ & 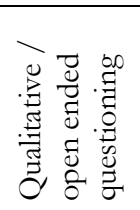 & 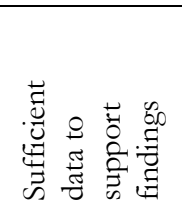 & 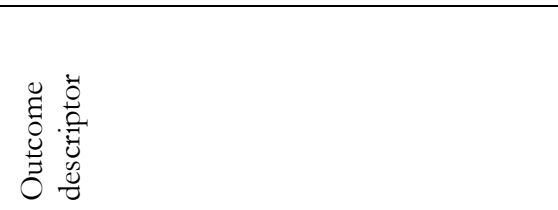 & 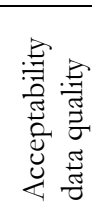 \\
\hline $\begin{array}{l}\text { Anderson, } \\
2010\end{array}$ & $\mathrm{~N}$ & $\mathrm{~N}$ & Likert scale - 12 q's (provided) - NV & Low \\
\hline $\begin{array}{l}\text { Barsevick et } \\
\text { al, } 2002\end{array}$ & $\mathrm{~N}$ & $\mathrm{~N}$ & $\begin{array}{l}\text { Interview - } 10 \text { closed q's (topics provided) } \\
-\mathrm{NV}\end{array}$ & Low \\
\hline $\begin{array}{l}\text { Beaver et al, } \\
2009\end{array}$ & $\mathrm{~N}$ & $\mathrm{U}$ & $\begin{array}{l}\text { Questionnaire designed and piloted - } \\
\text { NOS - NV }\end{array}$ & $\begin{array}{l}\text { Low } \\
\end{array}$ \\
\hline $\begin{array}{l}\text { Beaver et al, } \\
2012\end{array}$ & $\mathrm{~N}$ & Y & $\begin{array}{l}\text { Adapted Likert scale questionnaire - } \\
\text { (topics provided) - NV } \\
\text { Likert scale - overall satisfaction - NV }\end{array}$ & Low \\
\hline $\begin{array}{l}\text { Booker et } \\
\text { al, } 2004\end{array}$ & $\mathrm{~N}$ & $\mathrm{Y}$ & Closed q's (topics provided) - NV & Low \\
\hline $\begin{array}{l}\text { Cimprich et } \\
\text { al, } 2005\end{array}$ & $\mathrm{~N}$ & $\mathrm{Y}$ & Likert scale 1 closed q (provided) - NV & Low \\
\hline $\begin{array}{l}\text { Cirillo et al, } \\
2014\end{array}$ & $\mathrm{~N}$ & $\mathrm{U}$ & Rating scale - NOS $-\mathrm{NV}$ & Low \\
\hline $\begin{array}{l}\text { Cox et al, } \\
2005\end{array}$ & $\mathrm{~N}$ & $\mathrm{Y}$ & Adapted MISS (26 items) - NV & Low \\
\hline $\begin{array}{l}\text { Cox et al, } \\
2008\end{array}$ & $\mathrm{~N}$ & & $\begin{array}{l}\text { Likert scale questionnaire (4 domains } \\
\text { provided) - V }\end{array}$ & \begin{tabular}{|l|} 
Low \\
\end{tabular} \\
\hline $\begin{array}{l}\text { Craven et al } \\
2013\end{array}$ & $\mathrm{U}$ & $\mathrm{U}$ & Questionnaire (topics provided) - NV & Low \\
\hline $\begin{array}{l}\text { Delaney et } \\
\text { al, } 2009\end{array}$ & $\mathrm{~N}$ & $\mathrm{Y}$ & Likert scale 2q's - (provided) - NV & Low \\
\hline $\begin{array}{l}\text { Garrett et } \\
\text { al, } 2013\end{array}$ & $\mathrm{~N}$ & $\mathrm{~N}$ & $\begin{array}{l}\text { Likert scale questionnaire (topics } \\
\text { provided) - NV }\end{array}$ & Low \\
\hline $\begin{array}{l}\text { Hafiji et al, } \\
2012\end{array}$ & $\mathrm{~N}$ & $\mathrm{~N}$ & Likert scale questionnaire $-\mathrm{NOS}-\mathrm{NV}$ & Low \\
\hline $\begin{array}{l}\text { Hagopian \& } \\
\text { Rubenstein } \\
1990\end{array}$ & $\mathrm{U}$ & $\mathrm{U}$ & Questionnaire - NOS - NV & Low \\
\hline $\begin{array}{l}\text { Hegel et al, } \\
2011\end{array}$ & $\mathrm{~N}$ & $\mathrm{Y}$ & Likert scale 2q's (topics provided) - NV & Low \\
\hline $\begin{array}{l}\text { Heidrich et } \\
\text { al, 2009 } \\
\text { (Pilot Study 1) }\end{array}$ & $\mathrm{N}$ & $\mathrm{U}$ & $8 \mathrm{q}$ 's (topics provided) $-\mathrm{NV}$ & Low \\
\hline $\begin{array}{l}\text { Heidrich et } \\
\text { al, 2009 } \\
\text { (Pilot Study 2) }\end{array}$ & $\mathrm{N}$ & $\mathrm{U}$ & 8 q's (topics provided) - NV & Low \\
\hline $\begin{array}{l}\text { Heidrich et } \\
\text { al, 2009 } \\
\text { (Pilot Study 3) }\end{array}$ & $\mathrm{N}$ & $\mathrm{U}$ & 8 q's (topics provided) - NV & Low \\
\hline $\begin{array}{l}\text { Inman et al, } \\
2011\end{array}$ & $\mathrm{Y}$ & $\mathrm{U}$ & 1 closed q (provided) & Low \\
\hline $\begin{array}{l}\text { Jensen et al, } \\
2011\end{array}$ & $\mathrm{U}$ & $\mathrm{U}$ & $\begin{array}{l}\text { Likert questionnaire (topic provided) - } \\
\text { NOS - NV }\end{array}$ & Low \\
\hline Kelly, 1999 & $\mathrm{~N}$ & $\mathrm{U}$ & 4 closed q's (topics provided) - NV & Low \\
\hline $\begin{array}{l}\text { Kilbourn et } \\
\text { al, } 2013\end{array}$ & $\mathrm{~N}$ & $\mathrm{Y}$ & $\begin{array}{l}\text { Likert scale } 2 \text { closed q's (topics provided) } \\
-\mathrm{NV}\end{array}$ & Low \\
\hline $\begin{array}{l}\text { Kim et al, } \\
2011\end{array}$ & $\mathrm{~N}$ & $\mathrm{~N}$ & $\begin{array}{l}\text { Likert scale questionnaire (topics } \\
\text { provided) - NV }\end{array}$ & Low \\
\hline $\begin{array}{l}\text { Kimman et } \\
\text { al, } 2010\end{array}$ & $\mathrm{~N}$ & $\mathrm{~N}$ & PSQIII - V & Low \\
\hline $\begin{array}{l}\text { Leahy et al, } \\
2013\end{array}$ & $\mathrm{~N}$ & $\mathrm{~N}$ & $\begin{array}{l}\text { Adapted Satisfaction with Consultation } \\
\text { Scale - NV }\end{array}$ & Low \\
\hline
\end{tabular}




\begin{tabular}{|c|c|c|c|c|}
\hline $\begin{array}{l}\text { Livingston } \\
\text { et al, } 2010\end{array}$ & $\mathrm{~N}$ & $\mathrm{~N}$ & $\begin{array}{l}\text { Likert scale questionnaire (topics } \\
\text { provided) - NV }\end{array}$ & Low \\
\hline $\begin{array}{l}\text { Marcus et } \\
\text { al, } 1993\end{array}$ & $\mathrm{~N}$ & $\mathrm{~N}$ & $\begin{array}{l}\text { Single evaluation indicator (topic } \\
\text { provided) - NV }\end{array}$ & Low \\
\hline $\begin{array}{l}\text { Marcus et } \\
\text { al, } 2010\end{array}$ & $\mathrm{~N}$ & $\mathrm{Y}$ & $\begin{array}{l}\text { Questionnaire which component } \\
\text { most helpful (provided) - NV }\end{array}$ & Low \\
\hline $\begin{array}{l}\text { Mordenti et } \\
\mathrm{al}, 2013\end{array}$ & $\mathrm{~N}$ & $\mathrm{U}$ & Survey (topics provided) $-\mathrm{NV}$ & Low \\
\hline $\begin{array}{l}\text { Munro et al, } \\
1994\end{array}$ & $\mathrm{~N}$ & $\mathrm{~N}$ & Likert scale 1q (provided) - NV & Low \\
\hline $\begin{array}{l}\text { Reese et al, } \\
2012\end{array}$ & $\mathrm{~N}$ & $\mathrm{Y}$ & Likert scale 4q's (topics provided) - NV & Low \\
\hline $\begin{array}{l}\text { Reese et al, } \\
2014\end{array}$ & $\mathrm{~N}$ & $\mathrm{Y}$ & Likert scale 3q's - (topics provided) - NV & Low \\
\hline $\begin{array}{l}\text { Salonen et } \\
\text { al, } 2009\end{array}$ & $\mathrm{~N}$ & $\mathrm{Y}$ & $\begin{array}{l}\text { Revised likert scale questionnaire } \\
\text { (Kaunonen, 2000) - V }\end{array}$ & Low \\
\hline $\begin{array}{l}\text { Sandgren et } \\
\mathrm{al}, 2000\end{array}$ & $\mathrm{~N}$ & $\mathrm{~N}$ & Likert scale 4q's (provided) - NV & Low \\
\hline $\begin{array}{l}\text { Sardell et al, } \\
2000\end{array}$ & $\mathrm{~N}$ & $\mathrm{~N}$ & $\begin{array}{l}\text { Satisfaction questionnaire (topics } \\
\text { provided) - NV }\end{array}$ & Low \\
\hline $\begin{array}{l}\text { Smithies et } \\
\text { al, } 2009\end{array}$ & $\mathrm{~N}$ & $\mathrm{Y}$ & Likert scale 1q (topic provided) - NV & \\
\hline $\begin{array}{l}\text { Steginga et } \\
\text { al, } 2007\end{array}$ & $\mathrm{~N}$ & $\mathrm{Y}$ & Likert scale 1q (topic provided) - NV & Low \\
\hline $\begin{array}{l}\text { Young et al, } \\
2010\end{array}$ & $\mathrm{U}$ & $\mathrm{U}$ & Questionnaire - NOS - NV & Low \\
\hline $\begin{array}{l}\text { Young et al, } \\
2013\end{array}$ & $\mathrm{~N}$ & $\mathrm{Y}$ & $\begin{array}{l}\text { Likert scale } 13 \text { statements (provided) - } \\
\text { NV }\end{array}$ & Low \\
\hline $\begin{array}{l}\text { Zhang et al, } \\
2013\end{array}$ & $\mathrm{~N}$ & $\mathrm{Y}$ & Likert scale 1q (topic provided) - NV & Low \\
\hline
\end{tabular}

CST - coping skills training, MISS - Medical Interview Satisfaction Scale, N - No, NOS - Not Otherwise Specified, NV - Not Validated, PSQ III - Patient Satisfaction Questionnaire III, U - Unclear, V - Validated, Y - Yes 


\section{Table 8 Summary of Outcomes}

\begin{tabular}{|c|c|c|c|c|c|c|c|c|c|c|c|c|c|}
\hline & \multirow{3}{*}{\begin{tabular}{|l|} 
Intervention Category \\
Data Type
\end{tabular}} & \multicolumn{4}{|c|}{$\begin{array}{c}\text { TFU post initial diagnosis and } \\
\text { treatment }\end{array}$} & \multicolumn{4}{|c|}{$\begin{array}{c}\text { Side effect monitoring during/ } \\
\text { post treatment }\end{array}$} & \multicolumn{4}{|c|}{$\begin{array}{l}\text { Psycho-educational } \\
\text { interventions }\end{array}$} \\
\hline & & \multicolumn{2}{|c|}{$\begin{array}{l}\text { Qualitative } \\
\text { Data }\end{array}$} & \multicolumn{2}{|c|}{$\begin{array}{l}\text { Quantitative } \\
\text { Data }\end{array}$} & \multicolumn{2}{|c|}{$\begin{array}{l}\text { Qualitative } \\
\text { Data }\end{array}$} & \multicolumn{2}{|c|}{$\begin{array}{l}\text { Quantitative } \\
\text { Data }\end{array}$} & \multicolumn{2}{|c|}{$\begin{array}{l}\text { Qualitative } \\
\text { Data }\end{array}$} & \multicolumn{2}{|c|}{$\begin{array}{l}\text { Quantitative } \\
\text { Data }\end{array}$} \\
\hline & & High & Low & High* & Low & High & Low & High* & Low & High & Low & High* & Low \\
\hline \multirow{9}{*}{$\begin{array}{l}\text { Positive } \\
\text { Findings }\end{array}$} & Convenience & $\sqrt{ }$ & $\sqrt{ }$ & & $\sqrt{ }$ & $\sqrt{ }$ & $\sqrt{ }$ & & $\sqrt{ }$ & $\sqrt{ }$ & $\sqrt{ }$ & & $\sqrt{ }$ \\
\hline & $\begin{array}{l}\text { Familiar environment / facilitating sensitive } \\
\text { discussions }\end{array}$ & $\sqrt{ }$ & $\sqrt{ }$ & & & & & & & $\sqrt{ }$ & $\sqrt{ }$ & & $\sqrt{ }$ \\
\hline & Positive personal experiences & $\sqrt{ }$ & & & & $\sqrt{ }$ & $\sqrt{ }$ & & $\sqrt{ }$ & $\sqrt{ }$ & $\sqrt{ }$ & & $\sqrt{ }$ \\
\hline & Accessibility to $\mathrm{HCP} /$ continuity of care & $\sqrt{ }$ & & & $\sqrt{ }$ & $\sqrt{ }$ & $\sqrt{ }$ & & $\sqrt{ }$ & & & & \\
\hline & Support / reassurance & + & & + & & $\sqrt{ }$ & $\sqrt{ }$ & & $\sqrt{ }$ & $\sqrt{ }$ & $\sqrt{ }$ & & $\sqrt{ }$ \\
\hline & Positive aspects of intervention structure & $\sqrt{ }$ & $\overline{7}$ & 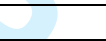 & & & & & & $\sqrt{ }$ & & & \\
\hline & Positive Patient $-\mathrm{HCP}$ relationship & & 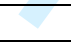 & 2 & $\sqrt{ }$ & & $\sqrt{ }$ & & $\sqrt{ }$ & & & & $\sqrt{ }$ \\
\hline & Prefer telephone based intervention & & & 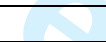 & & & $\sqrt{ }$ & & & & $\sqrt{ }$ & & \\
\hline & Overall satisfaction & & & 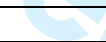 & $\sqrt{ }$ & & & & $\sqrt{ }$ & & $\sqrt{ }$ & & $\sqrt{ }$ \\
\hline \multirow{7}{*}{$\begin{array}{l}\text { Negative } \\
\text { Findings }\end{array}$} & Lack of contact - Peer / HCP & $\sqrt{ }$ & & & & & & & & & & & \\
\hline & Negative Patient $-\mathrm{HCP}$ relationship & $\sqrt{ }$ & & & 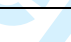 & & & & $\sqrt{ }$ & & $\sqrt{ }$ & & \\
\hline & Barrier to emotional discussions & & & & $\bar{c}$ & $\sqrt{ }$ & 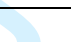 & & & & & & \\
\hline & Not useful for all patients & & & & & $\sqrt{ }$ & $\sqrt{ }$ & & & & & & $\sqrt{ }$ \\
\hline & Changes to Intervention structure & & & & & $\sqrt{ }$ & $\sqrt{ }$ & & $\sqrt{ }$ & $\sqrt{ }$ & $\sqrt{ }$ & & $\sqrt{1}$ \\
\hline & Lack of choice - receiving calls/ timing & & & & & & $\sqrt{ }$ & A & & & $\sqrt{ }$ & & \\
\hline & Preference for other intervention methods & & & & & & $i^{2}$ & 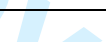 & $\sqrt{ }$ & & $\sqrt{ }$ & & $\sqrt{ }$ \\
\hline
\end{tabular}

HCP - Healthcare Professional, TC - telephone consultation

*no high quality data, $\sqrt{ }$ - at least one reported finding 